CD20-TCB induces IFNy/CXCL10-dependent T cell recruitment.

\title{
Cross-Linking of $T$ cell to $B$ cell lymphoma by the $T$ cell bispecific antibody CD20-TCB induces IFNY/CXCL10-dependent peripheral T cell recruitment in humanized murine model.
}

Floriana Cremasco*, Elena Menietti*, Dario Speziale, Johannes Sam, Stefano Sammicheli, Marine Richard, Ahmet Varol, Christian Klein, Pablo Umana, Marina Bacac, Sara Colombetti\#, Mario Perro $\#$.

Roche Innovation Center Zürich, Switzerland

* Equal Contribution

\# Equal Contribution

\$ correspondence to: mario.perro@roche.com

\section{Abstract}

Diffuse large B cell lymphomas (DLBCL) are a highly heterogeneous subtype of Non Hodgkin Lymphoma $(\mathrm{NHL})$, accounting for about $25 \%$ of $\mathrm{NHL}$ [1]. Despite an increased progression-free survival upon therapy, $40-50 \%$ of patients develop relapse/refractory disease, therefore there remains an important medical need [2]. T cell recruiting therapies, such as the CD20xCD3 T cell bi-specific antibody CD20-TCB (RG6026 or glofitamab), represent a novel approach to target all stages of DLBCL, especially those that fail to respond to multiple lines of treatment $[3,4]$. We aimed for a better understanding of the molecular features related to the mode of action (MoA) of CD20-TCB in inducing Target/T cell synapse formation and human $\mathrm{T}$ cell recruitment to the tumor. To directly evaluate the correlation between synapse, cytokine production and anti-tumor efficacy using CD20-TCB, we developed an innovative preclinical human DLBCL in vivo model that allowed tracking in vivo human T cell dynamics by multiphoton intravital microscopy (MP-IVM). By ex vivo and in vivo approaches, we revealed that CD20-TCB is inducing strong and stable synapses between human T cell and tumor cells, which are dependent on the dose of CD20-TCB and on LFA-1 activity but not on FAS-L. Moreover, despite CD20-TCB being a large molecule (194.342 kDa), we observed that intratumor CD20-TCB-mediated human T cell-tumor cell synapses occur within 1 hour upon CD20-TCB administration. These tight interactions, observed for at least 72 hours post TCB administration, result in tumor cell cytotoxicity, resident $\mathrm{T}$ cell proliferation and peripheral blood $\mathrm{T}$ cell recruitment into tumor. By blocking the IFNY-CXCL10 axis, the recruitment of peripheral T cells was abrogated, partially affecting the efficacy of CD20-TCB treatment which rely only on resident T cell proliferation. Altogether these data reveal 

made available under aCC-BY 4.0 International license.

CD20-TCB induces IFNY/CXCL10-dependent T cell recruitment.

that CD20-TCB's anti-tumor activity relies on a triple effect: i) fast formation of stable $T$ cell-tumor cell synapses which induce tumor cytotoxicity and cytokine production, ii) resident $\mathrm{T}$ cell proliferation and iii) recruitment of fresh peripheral T cells to the tumor core to allow a positive enhancement of the anti-tumor effect. 
bioRxiv preprint doi: https://doi.org/10.1101/2020.10.09.332874; this version posted October 9, 2020. The copyright holder for this preprint (which was not certified by peer review) is the author/funder, who has granted bioRxiv a license to display the preprint in perpetuity. It is made available under aCC-BY 4.0 International license.

CD20-TCB induces IFNy/CXCL10-dependent T cell recruitment.

\section{Introduction}

Diffuse large B-cell lymphoma (DLBCL) is the most common histological subtype of B-cell NHL accounting for $25-30 \%$ of diagnosed NHL $[5,6]$. The majority of DLBCL lymphomas occur in the lymph nodes, however about $30 \%$ of them occur in extranodal sites. Although heterogeneous, all DLBCL, including the extranodal types, share the characteristic expression of CD19 and CD20 on tumor cells. As a consequence, since the discovery of rituximab, a chimeric monoclonal antibody against CD20, the clinical practice standard of care for all forms of DLBCL is the combination of rituximab with chemotherapy (R-CHOP) [7, 8]. However, patients who fail to respond to first line treatment, or that develop resistance (40-50\%), have poor prognosis and DLBCL still represents a major medical need.

Currently, the use of T cell bi-specific antibodies targeting CD20 on tumor cells, e.g. CD20-TCB (also known as RG6026 or glofitamab), is a promising approach for the treatment of DLBCL [3, 4]. Indeed, CD20-TCB can redirect the activity of conventional CD4 and CD8 T cells against lymphoma cells by concomitant binding of CD20 on tumor cells and CD3 on T cells [3, 9]. Previous studies revealed that CD20-TCB has a long halflife and induces selective activation of conventional T cells, resulting in efficient tumor regression of the aggressive DLBCL xenograft model WSU DLCL2 in preclinical animal models in human stem cell humanized (HSC) NSG mice [3].Tumor regression has been also observed in several clinical trials of patient with $r / r$ DLBCL [10-13]. The treatment with such a potent CD20-TCB increases the risk of cytokine release syndrome (CRS) due to the peripheral cross-linking between T cell and B cells. Therefore, CD20-TCB administration is preceded by a single administration of Obinutuzumab (Gazyva), as a pretreatment (Gpt) to deplete circulating $\mathrm{CD} 20^{+}$cells and thus improve the safety of the first CD20-TCB administration [3]. Altogether, Gpt plus CD20-TCB represents a potent approach for the treatment of lymphoma patients and is currently being evaluated in multicenter Phase $\mathrm{I} / \mathrm{lb}$ studies in individuals with relapsed/refractory NHL (NCT03075696, NCT03467373, NCT03533283, NCT04077723). It has been demonstrated that clinical efficacy of checkpoint inhibitors (CPIs) positively correlates with the degree of conventional CD4 and CD8 T cell infiltration in the so called "inflamed" tumors, while tumors that are devoid of T cell infiltration ("immune desert") or that are only partially infiltrated ("immune excluded"), are generally poor responders to immunotherapies [14-16]. Interestingly, TCBs have shown to be efficacious even in tumors with poor immune cell infiltration and to convert, upon treatment, immune excluded and desert tumors into inflamed 
CD20-TCB induces IFNy/CXCL10-dependent T cell recruitment.

ones $[3,17,18]$. In view of the promising efficacy, it's important to elucidate the molecular features of CD20TCB activity, including: 1) how quickly CD20-TCB binds to tumor cells and induces T cell-target cells synapse formation; 2) which are the features of CD20-TCB mediated synapses; 3) for how long can CD20TCB mediate T cell engagement to tumor cells; 4) which are the molecular drivers that turn a desert tumor into an inflamed one after CD20-TCB treatment.

We took advantage of both in vitro and in vivo approaches. Live confocal in vitro imaging allowed in-depth description of CD20-TCB-mediated T cell-tumor cell synapses. In order to visualize the intra-tumor response of the human immune system to CD20-TCB in vivo, we imaged using multiphoton intravital microscopy (MPIVM) a newly set-up model of humanized mice with reduced xenoreaction that allow better analysis of $\mathrm{T}$ cell in vivo dynamics compare to previous models [19-21]. Using this technique, we were able to assess the kinetics and MoA of CD20-TCB in vivo, as well as highlighting the kinetics of TCB-induced cytotoxicity and identifying the mechanisms involved in CD20-TCB-dependent peripheral human $\mathrm{T}$ cell recruitment to tumors.

\section{Materials and Methods}

\section{$\underline{\text { Cell culture and labelling }}$}

WSU DLCL2 cells (human diffuse large B cell lymphoma) were originally obtained from ECACC (European Collection of Cell Culture) and deposited after expansion in the Roche Glycart internal cell bank. Cells were cultured in DMEM containing 10\% FCS.

OCI-Ly18 cells (human diffuse large B cell lymphoma) were originally obtained from Deutsche Sammlung von Mikroorganismen und Zellkulturen GmbH (DSMZ) and deposited after expansion in the Roche Glycart internal cell bank. Cells were cultivated in RPMI 1640 medium containing 10\% FCS and 1\% Glutamax.

CT26 cells (Mus Musculus colon carcinoma) were originally obtained from ATCC and after expansion deposited in the Roche Glycart internal cell bank, and were cultured in RPMI containing 10\% FCS and $1 \%$ Glutamax. 
CD20-TCB induces IFNy/CXCL10-dependent T cell recruitment.

All cells were cultured at $37{ }^{\circ} \mathrm{C}$ in a water-saturated atmosphere at $5 \% \mathrm{CO}_{2}$. All cell lines were tested negative to mycoplasma by PCR assay. Conventional pan T cells from the spleen of HSC-NSG mice were isolated using a CD2+ selection kit (Miltenyi Biotech, 130-091-114) and directly injected.

Conventional pan $\mathrm{T}$ cells or $\mathrm{CD}^{+} \mathrm{T}$ cells from peripheral blood mononuclear cells (PBMCs) were isolated from buffy coats (Blutspende Zurich) by negative magnetic isolation using Pan T cell isolation kit II (Miltenyi Biotech, 130-096-535) or CD8+ T cell isolation kit II (Miltenyi Biotech, 130-096-495), respectively. For in vitro activation, $\mathrm{CD}^{+} \mathrm{T}$ cells were cultivated at $1.5 \times 10^{6}$ cells $/ \mathrm{ml}$ in $\mathrm{CST}^{\mathrm{TM}}$ OpTimizer $\mathrm{T}$ cell expansion SFM medium (Thermo Fisher, A1048501) supplemented with $20 \mathrm{U} / \mathrm{ml}$ of recombinant hulL-2 (Roche, 11147528001) and then plated into 12 well plates previously coated for 2 hours RT with $1 \mu \mathrm{g} / \mathrm{ml}$ of huCD28.2 (BioLegend) and $1 \mu \mathrm{g} / \mathrm{ml}$ of human CD3ع (BioLegend). When needed, cells were fluorescently labeled with blue (10 $\mu \mathrm{M}$ CellTracker ${ }^{\mathrm{TM}}$ Blue CMAC Dye, , Thermo Fisher Scientific, C2110), red $\left(4 \mu \mathrm{M}\right.$ CellTracker ${ }^{\mathrm{TM}}$ Orange CMTMR Dye, Thermo Fisher Scientific, C2927) or green $(2.5 \mu \mathrm{M}$ CellTracker ${ }^{\mathrm{TM}}$ Green CMFDA Dye, Thermo Fisher Scientific, C2925), immediately before injection. Labeling was performed at $37^{\circ} \mathrm{C}$ for 20 minutes in RPMI medium without serum. When required, labeling with $1.25 \mu \mathrm{M}$ of CellTrace ${ }^{\mathrm{TM}}$ CFSE Cell proliferation kit (Thermo Fisher Scientific, C34554) has been performed in PBS at $37^{\circ} \mathrm{C}$ for 20 minutes.

\section{Flow cytometry}

Blood from HSC-NSG mice, PBMC-NSG mice or from human PBMCs was collected and lysed using BD Pharm Lyse (Cat. 555899). The blood lysates were then stained with the following panels: 1) muCD45 AF488 (BioLegend), huCD45 APCCy7 (BioLegend), huCD3 BV605 (BioLegend), huCD19 AF647 (BioLegend), huCD33 PerCp-Cy5.5 (BioLegend), NKp46 BV421 (BioLegend); 2) huCD45 APC Cy7 (BioLegend), huCD3 PerCp-Cy5.5 (BioLegend), GZB PE (eBiosciences), Ki-67 AF647 (BD); 3) CD62L APC-Cy7 (BioLegend), huCD45 PE (BioLegend), huCD3 BV605 (BioLegend), CD45RA BV711 (BioLegend).

For the evaluation of killing capacity, cells were stained with huCD8 AF700 (BioLegend) followed by Annexin V-PI staining according to manufacturer's instruction (BioLegend, APC Annexin V apoptosis detection kit with PI, 640932). 
bioRxiv preprint doi: https://doi.org/10.1101/2020.10.09.332874; this version posted October 9, 2020. The copyright holder for this preprint (which was not certified by peer review) is the author/funder, who has granted bioRxiv a license to display the preprint in perpetuity. It is made available under aCC-BY 4.0 International license.

CD20-TCB induces IFNy/CXCL10-dependent T cell recruitment.

Characterization of $\mathrm{T}$ cell activation has been evaluated with extracellular markers including: huCD3 BV605 (BioLegend), huCD8 BV510 (BioLegend), huCD8 AF700 (BioLegend), huCD4 AF488 (BioLegend), huCD69 BV421 (BioLegend), huCD69 AF647 (BioLegend), huCD25 BV711 (BioLegend). In order to discriminate between Live and Dead cells we always included Fixable Viability Dye eFlour ${ }^{\mathrm{TM}}$ 780 (eBioscience $\left.{ }^{T M}\right)$. When required cells were incubated for 4 hours with GolgiStop (BD) and GolgiPlug (BD), in order to allow intracellular cytokines accumulation, then cells were fixed and permeabilized according to the manufacturer's instruction (Fixation and Permeabilization Solution BD, 554714). Staining of intracellular cytokines has been performed with: hulFNy BV510 (BioLegend), huTNFa PE-Cy7 (BioLegend), huGZB FITC (BioLegend). Cells were run on a BD 5 laser LSR Fortessa. Data were analyzed using FlowJo V.10.

\section{$\underline{\text { In vitro confocal Imaging }}$}

For Live Confocal Imaging 200.000 WSU DLCL2 or OCl-Ly18 cells were stained with $10 \mu \mathrm{M}$ of CellTracker ${ }^{\mathrm{TM}}$ Blue CMAC Dye and then co-plated with 150.000 3T3 NIH Fibroblasts in 8-well plastictreated bottom slides (Ibidi, 80826). Cells were then incubated overnight at $37^{\circ} \mathrm{C}$. Before acquisition, CD3/CD28-activated CD8 ${ }^{+} \mathrm{T}$ cells were stained with $2.5 \mu \mathrm{M}$ of CellTracker ${ }^{\mathrm{TM}}$ Green CMFDA Dye and 40.000 labeled T cells were added to tumor cells. Alexa Fluor647-labeled CD20-TCB was added directly into the imaging wells at the indicated concentrations. Slides were imaged with a confocal microscope (inverted LSM 700, Zeiss) with a temperature and $\mathrm{CO}_{2}$-controlled stage. Live acquisition was performed with a 20x objective. Movies were collected using Zen software (Zeiss) coupled to the microscope, analyzed with Imaris (Bitplane; Oxford Instruments), and plotted using GraphPad Prism. For imaging on fixed samples, 500.000 WSU DLCL2 cells, stained with $10 \mu \mathrm{M}$ of CellTracker ${ }^{\mathrm{TM}}$ Blue CMAC Dye were plated on glass disc for imaging previously coated with Retronectin $\left(5 \mu \mathrm{g} / \mathrm{cm}^{2}\right)$. After $3 \mathrm{~h} 150.000$ CD3CD28-activated CD8 ${ }^{+} \mathrm{T}$ cells, were added to the tumor cells and incubated for 2 hours with CD20-TCB (200 ng/ml) and +/- aLFA1 antibody (Clone: TS 1/18, $10 \mu \mathrm{g} / \mathrm{ml}$, BioLegend, 302116). Cells were then gently washed, fixed and permeabilized according to manufacturer's instruction (Fixation and Permeabilization Solution BD, 554714). Non specific binding sites were saturated with 40 minutes incubation in PBS $+1 \%$ BSA. Cells were then stained with $0.2 \mu \mathrm{M}$ of Phalloidin AlexaFluor488 (A12379, Thermo Fisher Scientific) for 30min followed by staining with aLFA1-Alexa Fluor647 (Clone: CBR LFA 1/2, 
CD20-TCB induces IFNy/CXCL10-dependent T cell recruitment.

BioLegend, 366311) for 30 minutes. Slides were then mounted with FluorMount G (Southern Biotech, 0100-01) and imaged with a confocal microscope (inverted LSM 700, Zeiss). Acquisition was performed with a 20x objective. Images were then analyzed with Imaris (Bitplane; Oxford Instruments).

\section{In vitro killing assays}

100.000 WSU DLCL2 or OCI-Ly18 cells were plated together with CD3/CD28-activated CD8+ ${ }^{+}$cells or with freshly purified CD8 ${ }^{+} \mathrm{T}$ cells from PBMCs at the indicated ratios $(1: 1 ; 4: 1 ; 40: 1)$, into $96-\mathrm{U}$ bottomwells plates. CD20-TCB has been added at the indicated concentrations. When required, wells were supplemented with $10 \mu \mathrm{g} / \mathrm{ml}$ of aLFA1 antibody (Clone: TS 1/18, BioLegend, 302116) or with $10 \mu \mathrm{g} / \mathrm{ml}$ of aFAS-L antibody (BD, 556372). Cells were then incubated at $37^{\circ} \mathrm{C}$ in a water-saturated atmosphere at 5 $\% \mathrm{CO}_{2}$, and analyzed at the indicated time-points. When needed, supernatants were collected and stored at $-20^{\circ} \mathrm{C}$ and subsequently used for multiplexing analysis.

\section{$\underline{\text { Chemotaxis assays }}$}

Supernatants freshly derived from killing assay were immediately adopted for chemotaxis assays. $600 \mu \mathrm{l}$ of supernatant were placed in the bottom chamber of Corning ${ }^{\circledR}$ Transwell $^{\circledR}$ polycarbonate membrane cell culture inserts $6.5 \mathrm{~mm}$ Transwell with $5.0 \mu \mathrm{m}$ pore polycarbonate membrane insert (CLS3421). CD3CD28-activated $\mathrm{CD}^{+} \mathrm{T}$ cells were labeled with $2.5 \mu \mathrm{M}$ of CellTracker ${ }^{\mathrm{TM}}$ Green CMFDA Dye, then resuspended at $1^{*} 10^{6}$ cells $/ \mathrm{ml}$ in $\mathrm{CST}^{\mathrm{TM} O p T i m i z e r} \mathrm{~T}$ cell expansion SFM medium (Thermo Fisher, A1048501) without serum. $100 \mu \mathrm{l}$ of cell suspension was then seeded in the upper chamber of the transwell. After 3 hours of migration, cells migrated to the bottom chamber were collected and stained with CD8 AF700 (BioLegend) and resuspended in $200 \mu \mathrm{l}$ of PBS. $150 \mu \mathrm{l}$ of cell suspension was then acquired at constant flow rate $(2.5 \mu \mathrm{l} / \mathrm{sec})$ on a BD 5 laser LSR Fortessa. Data were analyzed using FlowJo V.10. \% of migrated cells has been calculated by applying this formula: $\frac{\text { Number of cells (found in the bottom chamber) }}{\text { Number of cells (seeded in the upper chamber) }} \times 100$. We then calculated the fold change of migration as compared to the untreated conditions (spontaneous migration).

\section{Multiplex}

100.000 WSU DLCL2 cells were seeded in DMEM + 10\% FCS + 1\% Glutamax, into 96-U bottom-wells plates, and treated with hulFNy at the indicated concentrations for $24 \mathrm{~h}$. Cell culture supernatant was 
CD20-TCB induces IFNy/CXCL10-dependent T cell recruitment.

stored at $-20{ }^{\circ} \mathrm{C}$ and subsequently analyzed together with supernatant derived from killing assays with the Bio-Plex Pro' ${ }^{\mathrm{TM}}$ Human Chemokine Panel, 40-Plex (\#171AK99MR2) following manufacturer's instructions. Samples were then run on Bio-Plex® 200 System. Data were plotted and analyzed with GraphPad Prism.

\section{$\underline{\text { In vivo studies in mice }}$}

All animal protocols were approved by the Cantonal Veterinary Office in Zürich (license ZH193/2014). Mice were NSG (Taconic) mice, aged 10-14 weeks at start of experiments and maintained under specific pathogen free condition with daily cycles of $12 \mathrm{~h}$ light and $12 \mathrm{~h}$ darkness according to committed guidelines (GV-Solas, Felasa, TierschG). After arrival, animals were maintained for one week to get accustomed to their new environment and for observation. Continuous health monitoring was carried out on a regular basis. For all experiments we adopted $25 \mathrm{~g}(+/-5 \mathrm{~g})$ female NSG mice. Mice included in the study were allocated into groups after randomization with a dedicated software.

\section{Skinfold chamber model}

The skinfold chamber surgery was performed according to previously described procedures [22]. NSG mice were anesthetized using isoflurane (1-5\%) in combination with an air-oxygen mixture, and placed on a heating pad. Mice were then shaved with a razor followed by hair-removal cream admixed 50:50 with hydrating cream. After the formation of a dorsal skin fold, a round piece of skin of approximately 10 $\mathrm{mm}$ diameter was removed from the first layer in the fold, as well as the superficial layer of fat underneath with the visual aid of a stereomicroscope, exposing the vasculature on the opposite side. The skinfold chamber (APJ trading) was then fixed to the animal with screws pierced through the skin, and secured by suturing the upper edge. Finally, the exposed skin layer was rinsed with saline solution and a coverslip was fixed onto the chamber by a spanning ring. All procedures were performed under a sterile hood in sterile conditions. Mice were allowed to wake under a warming infrared lamp, and provided with a painkiller for $48 \mathrm{~h}$. After at least $48 \mathrm{~h}$ recovery time, mice were anesthetized again by isoflurane, and the coverslip removed. With the visual aid of a stereomicroscope, the desired cell mixture for each experiment was then injected intradermally, 2 injections of $25 \mu$ l per mouse, together with the treatment stated in the 
CD20-TCB induces IFNy/CXCL10-dependent T cell recruitment.

figure legends, and the coverslip replaced. Mice were then allowed to recover under an infrared lamp, and eventual intravenous administration of drugs was performed concomitantly.

\section{Intravital 2 photon Imaging}

2 photon microscopy was performed on a Zeiss 710 combined confocal and multiphoton system using a 20x objective (Plan Apochromat, Zeiss, N/A=1). Mice were anesthetized by isoflurane (1-5 \%) in combination with an air-oxygen mixture, and kept at a constant temperature of $37^{\circ} \mathrm{C}$ by using an ad-hoc built incubator. By adopting an excitation wavelength of $770 \mathrm{~nm}$, with a laser power of 16 , we achieved simultaneous excitation of the dyes. Sequential 3D stacks of $40 \mu \mathrm{m}$ at $4 \mu \mathrm{m}$ step sizes were acquired at $45 \mathrm{sec}$ intervals. Acquisition settings were kept constant between groups: length of the movie, z-stack size and speed of acquisition. For the time course acquisition of T cell tracks and speed at $24 \mathrm{~h}, 48 \mathrm{~h}$ and $72 \mathrm{~h}$ the same batch of animals has been imaged for 1 hour at the indicated time points.

\section{Movie analysis}

T cell dynamics and T cell-tumor interactions were calculated using automated image analysis. For each movie, T cells and tumor cells were identified and tracked using the surface module of IMARIS software version 9.2.1, 9.3.1 and 9.5.1 (Bitplane). Cell positions were exported and processed using a custom developed Python extension. Data from appropriate movies were then aggregated and processed by a customized pipeline in Tibco Spotfire, and statistical analysis was calculated as stated in the figure legends via GraphPad Prism Version 6 and Version 7.

\section{Generation of humanized mice}

NSG female mice (Taconic) aged 5 weeks were injected with Busulfan (15 mg/kg) followed by an injection of 100.000 human CD34+ cord blood cells (StemCellTechnologies) 24h later. 15 weeks after injection, humanized mice were screened for human T-cell frequencies by flow cytometry. Only humanized mice that revealed a humanization rate greater than $25 \%$ were used for efficacy studies.

\section{Efficacy study}

1.5 * $10^{6}$ WSU DLCL2 in 50\% GFR Matrigel admixed with 50\% RPMI were injected subcutaneously in HSCNSG mice and the tumors were allowed to grow for approximately 20 days. Mice were assigned randomly into groups, by adopting a dedicated software. Only mice with a tumor volume between 200 and $800 \mathrm{~mm}^{2}$ 
CD20-TCB induces IFNy/CXCL10-dependent T cell recruitment.

have been included in the studies. CD20-TCB treatment was administered intravenously once per week at $0.5 \mathrm{mg} / \mathrm{kg}$. Anti-human IFNy (Bio X Cell, BE0235) or anti-human CXCL10 (ThermoFisher Scientific, MA523726S) was administered intravenously concomitantly with CD20-TCB in the designed groups. Tumor size was measured 3 times per week, scouts were taken 24 hours post second treatment. The subcutaneous tumors were resected and fixed in PFA 4\% and later processed for FFPET (VIP6 Al, Sakura). $4 \mu \mathrm{m}$ paraffin sections were subsequently cut in a microtome (Leica RM2235, Germany). Hematoxylin and Eosin staining was performed using standard protocol. Immunohistochemistry was performed in paraffin sections with the indicated anti-human antibodies: CD3 (SP7, Thermofisher); CD31 (DIA310, dianova); IFNy (ab231036, Abcam); CXCL10 (LS-C312561, LS-Bio); CXCR3 (LS-B10183, LS-Bio); Ki67 (790-4286); DAPI (760-4196), by adopting the Leica autostainer platform following the manufacturer's protocols (Leica Biosystems, Germany). CD3/CD31 duplex images were obtained with Iscan HT (Ventana) and analyzed with Definiens software for cell quantification. CXCR3, Ki67, IFNy and CXCL10 images were obtained with a Vectra Polaris scanner and analyzed with Halo software for cell quantification.

\section{Statistical analysis}

Statistical analysis was performed using Graph Pad Prism Version 6 and Version 7, and statistical tests were applied as stated in the figure legends. 
bioRxiv preprint doi: https://doi.org/10.1101/2020.10.09.332874; this version posted October 9,2020 . The copyright holder for this preprint (which was not certified by peer review) is the author/funder, who has granted bioRxiv a license to display the preprint in perpetuity. It is made available under aCC-BY 4.0 International license.

CD20-TCB induces IFNy/CXCL10-dependent T cell recruitment.

\section{Results}

\section{CD20-TCB-mediated killing requires the formation of stable T effector cell-tumor cell synapses}

To characterize the cellular and molecular mechanisms of CD20-TCB-induced tumor cell killing, we analyzed the killing capacity of CD8 ${ }^{+} T$ cells against two DLBCL cell lines: WSU DLCL2, and OCl-Ly18 (Fig. 1a, Fig. supplementary 1a, 1b, 1f). We postulate that several intrinsic features of DLBCL models, including CD20 and ICAM-1 expression level, might modulate the sensitivity to treatment with CD20-TCB. Killing experiments aimed to correlate CD20 and ICAM expression with efficacy of killing in several DLBCL cell line showed that, there is no general correlation between those two factors when many cell lines are evaluated (data not shown), arguing in favor that there are several parameters involved in the tumor cell killing mediated by CD20-TCB. However, it is difficult to identify all factors that modulate killing in several lines of DLBCL by blocking several proteins involved in different step of the T cell killing pathway. In contrast, the formation of stable immune synapses between a human $\mathrm{CD} 8^{+} \mathrm{T}$ cell and a target cell is a fundamental step for T cell mediated cytotoxicity regardless of targeted tumor cells [23]. We thus hypothesized that the heterogeneity observed in CD20-TCB-mediated killing may rely on different functionality and stability of the formed immunological synapses. In order to investigate synapse formation in vitro, we took advantage of live confocal imaging and IMARIS built-in tracking algorithm to assess i) T cell dynamics (speed and movements direction); ii) T cells-tumor cells time of interaction and iii) area at the contact site over time. These three parameters help us defining "stable synapses". We observed that CD20-TCB induces synapse formation between CD8 ${ }^{+}$T cells and both WSU DLCL2 or OCl-Ly18 cells (Fig. 1b, supplementary Videos 1-4) and, further supporting the hypothesis that these contacts mediate cytotoxic synapses, we observed polarization of the cytotoxic molecule Granzyme B toward the synapse (Fig. 1c). Further analysis revealed that while T cells in untreated conditions are randomly moving, searching for a target, with a speed of $\sim 4$ $\mu \mathrm{m} / \mathrm{min}$ (Fig. 1d, untreated), CD20-TCB treatment leads to a significant decrease in T cell speed (Fig. 1d). Comparison of WSU DLCL2 and OCI-Ly18 cells revealed that the reduction in T cell speed is greater when CD8 $^{+}$T cells target WSU DLCL2 cells, as compared to OCl-Ly18 cells (Fig. 1 d). In line with this, more T cells form interactions longer than 20 minutes when targeting WSU DLCL2 cells (Fig. 1e). Furthermore, we observed that decreasing concentrations of CD20-TCB lead to less contact duration between T cell-target cells (Fig. 1f) and to a smaller area at the contact site (Fig. 1g), supporting the role of CD20-TCB in tuning T cell-tumor cell synapse formation. Moreover, lower doses of CD20-TCB impair T cell speed, resulting in speed values similar to those found in untreated conditions (Fig. 1h). Altogether, these data revealed that analysis of synapse formation between T cells and tumor cells, as a function of their motility and dynamic interactions in vitro, could be informative of T cells killing capacity upon CD20-TCB treatment In support of the idea that stable synapses are required for efficient CD20-TCB-mediated tumor cell killing, we observed that the integrin protein with key functions in synapse formation and stabilization, LFA-1 [24], localizes at the synapse site (Fig. 1i). Furthermore, while inhibition of FAS-L, an apoptosis trigger molecule, did not impact CD20-TCB mediated killing, LFA-1 inhibition decreased CD20-TCB mediated killing both in WSU 
bioRxiv preprint doi: https://doi.org/10.1101/2020.10.09.332874; this version posted October $9,2020$. The copyright holder for this preprint (which was not certified by peer review) is the author/funder, who has granted bioRxiv a license to display the preprint in perpetuity. It is made available under aCC-BY 4.0 International license.

CD20-TCB induces IFNy/CXCL10-dependent T cell recruitment.

DLCL2 cells (Fig. 1j) and in OCl-Ly18 cells (Fig. supplementary 1c), without affecting T cells viability (Fig. supplementary 1d). However, killing capacity at high dose of CD20-TCB $(200 \mathrm{ng} / \mathrm{ml})$ is unaffected by LFA-1 inhibition. Indeed, despite LFA-1 not localizing at the synapse site upon inhibition, T cells still present actin polarization and form synapses (Fig. supplementary 1e), suggesting that a high dose of CD20-TCB can induce a stable synapse formation independently of LFA-1 engagement.

These data revealed that CD20-TCB activity requires the formation of stable cytotoxic synapses and that the stability of these synapses correlates with the killing capacity. This parameter, which can be efficiently measured by live imaging approaches, is therefore key to explain the heterogeneity of the response of CD20-TCB against different cell lines of DLBCL. Despite peculiar features of target cells such as expression of CD20, ICAM-1 and LFA-1 might explain difference in killing between WSU and OCI-Ly18, they do not suffice to explain heterogeneity observed in other human DLBCL cell lines (Fig. supplementary 1f and data not shown), leaving the stability of synapse formation the main read-out correlating with efficiency.

\section{A xenoreaction-free model for the visualization and quantification of infiltrating $\mathrm{T}$ cell dynamics in response to therapy}

The selective binding of CD20-TCB to human CD20 on cancer cells, urged us to develop a suitable imaging model in order to visualize the response to CD20-TCB in the context of a human immune system in vivo. To this aim we developed an MP-IVM imaging experimental design in which we implanted a dorsal skinfold chamber in recipient NSG mice followed by intradermal injection of CMAC-Blue stained human DLBCL cells (WSU DLCL2) together with unstained murine CT26 cells, CMFDA-labeled human T cells and +/- AlexaFluor labeled CD20-TCB (Fig. 2a) [22]. To set up our MP-IVM studies we adopted two different sources of human T cells for the skinfold chamber of NSG mice, and we then compared the two humanized mouse models derived from these transfers. In one model (PBMC-NSG), we transferred labelled T cells derived from human peripheral blood mononuclear cells (PBMCs) in immune-deficient NSG mice. However, while this model is known to allow human T cell engraftment, it is prone to graft versus host disease (GvHD) due to strong xenoreaction of human T cells against the murine host tissue [25]. The second humanized model (HSC-NSG-NSG) was obtained by transferring in the skinfold chamber implanted in NSG mice human T cells derived from HSC-NSG mice. HSC-NSG mice were generated by transferring human hematopoietic stem cells (HSCs) from the cord blood of healthy donors into Busulfan pre-conditioned (and therefore 
bioRxiv preprint doi: https://doi.org/10.1101/2020.10.09.332874; this version posted October 9,2020 . The copyright holder for this preprint (which was not certified by peer review) is the author/funder, who has granted bioRxiv a license to display the preprint in perpetuity. It is made available under aCC-BY 4.0 International license.

CD20-TCB induces IFNy/CXCL10-dependent T cell recruitment.

depleted of endogenous bone marrow) NSG mice [26]. In this latter model, human T cells, after generation in the bone marrow, undergo selection in the murine thymus and are therefore tolerant to mouse tissue, thus minimizing xenoreaction. We adopted WSU DLCL2 cells for our in vivo imaging model, since in vitro experiments revealed that WSU DLCL2 targeting leads to more stable synapses as compared to OCI-Ly18 (Fig. 1b-d), thus providing a powerful tool for investigating T cell dynamics in vivo in the context of CD20TCB treatment. CT26 murine cells have been mainly adopted for technical reasons, as having WSU DLCL2 cells interspaced by CT26 cells allows for better segmentation of cells during post acquisition analysis, and therefore for a more precise quantification of T cell-target cell interactions. Moreover, the addition of CT26 cells allows the recreation of physiological heterogeneity within the implanted human tumor. Notably, CD20TCB only targets WSU DLCL2 and not CT26 cells, and as CT26 cells are from a BALB/C background, thus sharing the expression of major histocompatibility complexes with NSG mice, tolerized T cells should not recognize them and cause alloreaction. Therefore, the introduction of CT26 cells in our model should not have an impact on tolerized $\mathrm{T}$ cells dynamics. We demonstrated that this approach allows for the simultaneous visualization, by MP-IVM, of tumor cells (blue), T cells (pink) and CD20-TCB (white) in three different channels (Fig. supplementary 2a). In line with our in vitro observations, we could confirm that CD20-TCB binds concomitantly to tumor cells and T cells, forming visible clusters of increased drug density on the membrane of $\mathrm{T}$ cells (Fig. 2b). Comparison of $\mathrm{T}$ cell dynamics revealed that $\mathrm{T}$ cells derived from PBMCs show a low motility both in the vehicle group (supplementary Video 5) and upon CD20-TCB treatment (supplementary Video 6). In contrast, T cells from HSC-NSG mice were highly motile in the vehicle group (supplementary Video 7), and slowed down visibly upon CD20-TCB treatment (supplementary Video 8). To portray differences in T cell dynamics we displayed flower plots of tracks according to their displacement in the $X$ and $Y$ axes (Fig. 2c). Tracks that go farther from the origin indicate lack of interaction with the surrounding tissue, while tracks that stay closer to the origin indicate a stronger interaction between T cells and the surrounding environment. The tracks of T cells in PBMC-NSG mice are not spreading far from the center, both in the CD20-TCB treated animals and in the vehicle (Fig 2c, top), suggesting that in this model T cells interact with the tissue regardless of the treatment (xenoreactivity), thus providing an insufficient ability to evaluate differences in T cell dynamics upon therapy. On the contrary, T cells from HSC-NSG mice, when treated with CD20-TCB, displayed a track dispersion far lower than mice 
CD20-TCB induces IFNy/CXCL10-dependent T cell recruitment.

receiving only the vehicle (Fig. 2c, bottom). In line with this, T cells in PBMC-NSG mice were almost immotile both in the untreated and CD20-TCB treated group (Fig. 2d). In contrast, HSC-NSG derived T cells had an average speed of $6 \mu \mathrm{m} / \mathrm{min}$ in vehicle treated mice, which dropped to $3 \mu \mathrm{m} / \mathrm{min}$ upon CD20-TCB treatment (Fig. 2d), recapitulating our in vitro observations (Fig. 1g). Furthermore, T cells from PBMCs displayed no visible changes in track displacement from point $A$ to point $B$ in the acquisition frame, between untreated and treated groups (Fig. 2d). By contrast, the track displacement of HSC-NSG-derived T cells was significantly different between the vehicle and the treated groups (Fig. 2d), meaning that, without treatment, $\mathrm{T}$ cells are randomly moving and explore the environment far from their starting point, while CD20-TCB leads to T cells moving in a neighborhood closer to the starting point. These data revealed that by using our imaging experimental design we are able to visualize CD20-TCB impact on human T cell dynamics. Moreover, we were able to identify and describe the xenoreaction, which affects T cell dynamics in the intradermal region when utilizing human T cells originated from PBMCs. Further supporting the finding that PBMCs-derived T cells are immotile in the skinfold chamber due to ongoing xenoreaction with the host murine tissue, analysis of blood composition of PBMC-NSG mice revealed an increased proportion of strongly activated $C D 8^{+} \mathrm{T}$ cells expressing Granzyme B and Ki67, a phenotype consistent with the ongoing GvHD (Fig. supplementary 2b-c). By contrast, HSC-NSG mice are characterized by a higher \% of circulating naïve $T$ cells, defined as CD45RA+ CD62L $L^{+}$(Fig. supplementary 2d). These observations support the finding that T cells from HSC-NSG mice are tolerized in the murine thymus and therefore do not mediate xenoreaction.

In conclusion, the model adopting HSC-NSG-mice-derived T cells constitutes the best approach to our aims as it minimizes xenoreaction and recapitulates CD20-TCB in vitro observations. Indeed, as observed in vitro

(Fig. 1g), CD20-TCB leads to decreased speed in T cell movements which is a consequence of the formation of functional synapses between T cells and target cells.

\section{CD20-TCB induces early and lasting T cell engagement and activity}

Co-injection of CD20-TCB with tumor cells and T cells in the skinfold chamber revealed an early interaction of T cells with the tumor (Fig. 2). However, this approach does not constitute a proper setting to describe 
bioRxiv preprint doi: https://doi org/10.1101/2020.10.09.332874; this version posted October 9,2020 . The copyright holder for this preprint

(which was not certified by peer review) is the author/funder, who has granted bioRxiv a license to display the preprint in perpetuity. It is made available under aCC-BY 4.0 International license.

CD20-TCB induces IFNy/CXCL10-dependent T cell recruitment.

CD20-TCB pharmacokinetics, as the drug is directly administered into the tumor not allowing the analysis of the impact of whole body distribution. To overcome this limitation, in a new set of experiments we administered CD20-TCB intravenously, aiming at understanding a) how long does it take for the drug to reach the tumor site and start inducing $T$ cell-tumor cell interactions, as well as b) the duration of these interactions. In order to depict the degree of T cell-tumor cell interactions, we calculated different parameters from MP-IVM videos: $T$ cell speed, track displacement from point $A$ to point $B$ in the acquisition frame, and arrest coefficient, which represents the percentage of T cells with a speed lower than the $2 \mu \mathrm{m} / \mathrm{sec}$ threshold. In order to understand the time point at which the CD20-TCB-induced stable contacts between T cells and tumor cells start to form, we determined an arbitrary threshold for "significant contact stability" by calculating the average values of the interaction parameters at $24 \mathrm{~h}$ post therapy (a time point in which we know the interactions are stable upon treatment) (Table 1).

Upon intravenous administration of CD20-TCB, the speed and track displacement of $\mathrm{T}$ cells decreased significantly and the arrest coefficient increased significantly, when compared to the vehicle, as early as 30 minutes after injection (supplementary videos 9-14). However, the arbitrary threshold (shown as a dotted line), was reached at around 1-2 hours after therapy (Fig. 3a) for each of the parameters analyzed. These data suggest that CD20-TCB, despite being a large molecule (194.342 kDa), reaches the tumor site and acts on the resident $T$ cells inducing $T$ cell-tumor cell interaction early after systemic administration.

It is possible to visually appreciate the effect of CD20-TCB by observing 3 different behaviors of the T cells in vivo: i) a T cell migrating and suddenly recognizing a tumor cell and start interacting with the same; ii) a $\mathrm{T}$ cell interacting from the beginning of the observation with a tumor cell, and iii) a $T$ cell that does not interact, possibly because it has not been engaged by CD20-TCB yet (Supplementary video 15, Fig. 3b). Our observation confirms that CD20-TCB acts early upon injection (behavior ii), but also suggests a gradual effect of CD20-TCB on T cell dynamics (behavior i and possibly behavior iii).

To address the question of the duration of CD20-TCB-mediated T cell-tumor cell synapses, we investigated the interaction indexes at the tumor site at later time points. Flower plots of track displacement at 24,48 and 72 hours consistently showed less dispersed tracks in the CD20-TCB treated tumors, suggesting a higher engagement of T cells at all time-points upon CD20-TCB treatment as compared to vehicle (Fig. 3c and 
CD20-TCB induces IFNY/CXCL10-dependent T cell recruitment.

supplementary video $16-21$ ). More in detail, analysis at 24,48 and 72 hours post CD20-TCB injection revealed that both $\mathrm{T}$ cell speed and track displacement (distance covered by a single cell in a given time) decreased significantly when comparing vehicle vs treatment group. (Fig. 3d-e). These data indicate that T cells form stable synapses with tumor cells also at later time-points upon CD20-TCB injection. The arrest coefficient values (percentage of cells moving slower than $2 \mu \mathrm{m} / \mathrm{min}$ at a given time point) also support the great stability and functionality of CD20-TCB induced synapses at all measured time-points. Indeed, in the treated group more than $70 \%$ of the cells were arrested at 24,48 and 72 hours, while in the vehicle group always less than $56 \%$ of cells were arrested (Fig.3f). Similarly, contact duration increased strongly upon treatment compared to the vehicle at all time-points, and the percentage of long term contacts (more than 20 minutes) increased remarkably when comparing vehicle vs CD20-TCB, with the biggest difference at 24 hours (Fig. 3g). Overall, these data indicate a higher frequency and longer duration of T cell-tumor cell interactions in mice treated with CD20-TCB as compared to vehicle controls, not only at early, but also at late time points.

Altogether, these data show that CD20-TCB-dependent T cell-tumor cell interactions start gradually at early time points and persist at later time points. Moreover, the observation that CD20-TCB treatment leads to increased proportion of Granzyme B or Perforin expressing CD8 ${ }^{+}$T cells over time (Fig. supplementary 3 a-b) led us to conclude that these stable and persistent interactions are bona fide cytotoxic synapses, in line with those observed in vitro (Fig. 1 c). However, besides CD20-TCB-mediated cytotoxicity, previous works had suggested that CD20-TCB could have additional activities within the tumor. Indeed, it has been observed that upon CD20-TCB treatment, an increased amount of intra-tumor T cells can be observed [3], possibly due to $\mathrm{T}$ cell influx form the periphery; however, the origin of this $\mathrm{T}$ cell influx has never been investigated.

CD20-TCB treatment induces both the expansion of pre-existing intra-tumor resident $\mathrm{T}$ cells and the recruitment of peripheral blood T cells 
bioRxiv preprint doi: https://doi.org/10.1101/2020.10.09.332874; this version posted October 9,2020 . The copyright holder for this preprint

(which was not certified by peer review) is the author/funder, who has granted bioRxiv a license to display the preprint in perpetuity. It is made available under aCC-BY 4.0 International license.

CD20-TCB induces IFNy/CXCL10-dependent T cell recruitment.

We have demonstrated that CD20-TCB is able to mediate human T cell-tumor cell interactions in the presence of resident human T cells within 1 hour upon intravenous injection (Fig 3). Moreover, in line with previous observations [3], we confirmed that CD20-TCB treatment leads to an increased number of $C D 3^{+} \mathrm{T}$ cells in the tumor, as revealed by histology analysis of subcutaneously injected WSU DLCL2-derived tumors

(Fig. 4a). However, it is still not known whether the increased number of human $\mathrm{CD}^{+} \mathrm{T}$ cells could originate by resident $\mathrm{T}$ cell proliferation, recruitment from the periphery, or both. To this aim we collected tumors $24 \mathrm{~h}$ post second injection of CD20-TCB or vehicle and performed histological quantification of intra-tumoral $\mathrm{CD}^{+} \mathrm{T}$ cells expressing i) Ki67, a proliferation marker; ii) $\mathrm{CXCR} 3$, the main receptor mediating recruitment of T cells to focal sites [27]. Our analysis revealed that CD20-TCB leads to increased counts of both CD3 ${ }^{+}$ $\mathrm{Ki}^{+} 7^{+}$(Fig 4b) and $\mathrm{CD}^{+} \mathrm{CXCR}^{+}$(Fig 4c) cells, as compared to the vehicle, leading to the conclusion that CD20-TCB treatment leads to both proliferation of resident $T$ cells and active recruitment of peripheral $\mathrm{CXCR}^{+}$cells. In vitro analysis revealed that CD20-TCB mediates early T cell activation, as demonstrated by CD69 and CD25 increased expression early upon treatment (Fig. supplementary 4a), as well as T cell proliferation, (Fig. 4d).

In order to investigate the mechanism by which CD20-TCB activity within the tumor mediates peripheral human T cell recruitment in vivo, we adapted our skinfold chamber model. As the focus of the study are the mechanisms of active recruitment mediated by the activity of the drug within the tumor, we injected labelled resident $T$ cells together with the tumor and the TCB intradermally, in order to provide a model of an "inflamed" tumor in which the drug is already active. At the same time, we injected differently labelled T cells intravenously. In the presence of any recruiting mechanism dependent on the CD20-TCB activity within the tumor, the peripheral T cells would be recruited to the tumor site, and would be easily distinguishable from their resident counterpart (Fig. 4e). Our results clearly demonstrated that treatment with CD20-TCB strongly increases the intra-tumor infiltration of peripheral blood T cells (orange) as compared to the vehicle (Fig. 4f), increasing the amount of $T$ cells $/ \mathrm{mm}^{2}$ from an average of 6 cells $/ \mathrm{mm}^{2}$ in the vehicle to $50 \mathrm{cells} / \mathrm{mm}^{2}$ in the CD20-TCB treated group (Fig. $\mathbf{4 g}$ ).

In line with the observation that intravenous injection of CD20-TCB leads to early and lasting activity, intradermal CD20-TCB retains the ability to stimulate the interaction between resident $\mathrm{T}$ cells and tumor cells at 72 hours post treatment. Indeed, also in this setting, T cells interacted more with the tumor in the 
bioRxiv preprint doi: https://doi org/10.1101/202010.09.332874; this version posted October 9,2020 . The copyright holder for this preprint

(which was not certified by peer review) is the author/funder, who has granted bioRxiv a license to display the preprint in perpetuity. It is made available under aCC-BY 4.0 International license.

CD20-TCB induces IFNy/CXCL10-dependent T cell recruitment.

presence of CD20-TCB, as shown by the decrease in the speed index from an average of $5 \mu \mathrm{m} / \mathrm{min}$ in the vehicle to an average of $2.5 \mu \mathrm{m} / \mathrm{min}$ in the treated group. Likewise, track displacement and the arrest coefficient indexes indicated a higher T cell-tumor cell interaction in the treated vs untreated group. Moreover, the recruited $\mathrm{T}$ cells showed interaction parameters similar to the resident $\mathrm{T}$ cells in the treated group, supporting the finding that CD20-TCB can still bind freshly recruited T cells and is functional at 72 hours post administration (Fig. supplementary 4b).

An important question to answer, is whether the presence of resident intra-tumor $\mathrm{T}$ cells at baseline is required to induce further T cell influx upon CD20-TCB treatment, and most importantly, whether there is a threshold of baseline infiltration required to mediate this secondary recruitment effect. To address these questions, we injected decreasing $T$ cell-tumor cell ratios intradermally, and quantified the ability to recruit peripheral T cells upon CD20-TCB treatment. A 1:1 proportion of T cells vs tumor cells allowed to recruit a strikingly high number of peripheral blood T cells (up to 111 cells per tumor, with a minimum of 79 cells per tumor); decreasing the ratio to $1: 10$ or $1: 100$ strongly decreased the recruitment capability, although this was still retained (up to 37 cells per tumor). Notably, with no resident human T cells injected, the number of peripheral human $\mathrm{T}$ cells found in the tumor was extremely low (maximum 15 cells per tumor), similarly to the number of peripheral $\mathrm{T}$ cells detected in the vehicle group. These findings strongly suggest that the presence of a certain amount of resident $T$ cells is necessary to trigger the initial inflammation and $T$ cell proliferation as well as to induce peripheral T cell recruitment upon TCB treatment (Fig. 4h), hence transforming a desert tumor, with limited number of resident T cells, in an inflamed tumor.

By in vitro chemotaxis assays, we showed that supernatants derived from WSU DLCL2 co-cultured with $\mathrm{CD}^{+} \mathrm{T}$ cells and treated with CD20-TCB lead to peripheral human $\mathrm{T}$ cells recruitment (from the top chamber) (Fig. 4i, ratio 1:1). Moreover, we observed that supernatants derived from lower T cell-tumor cells ratios have a lower attractant capacity (Fig. 4i). Altogether, these data suggest an active recruitment activity exerted by resident T cells when exposed to CD20-TCB. However, the mechanism through which CD20-TCB leads to the recruitment of peripheral human T cells still remains to be elucidated.

\section{CD20-TCB-induced peripheral T cell recruitment is dependent on the IFNY-CXCL10 axis.}


bioRxiv preprint doi: https://doi.org/10.1101/2020.10.09.332874; this version posted October 9,2020 . The copyright holder for this preprint (which was not certified by peer review) is the author/funder, who has granted bioRxiv a license to display the preprint in perpetuity. It is made available under aCC-BY 4.0 International license.

CD20-TCB induces IFNy/CXCL10-dependent T cell recruitment.

Based on the finding that CD20-TCB mediates the recruitment of peripheral human T cells into the tumor, we hypothesized that this might be mediated by chemokines released after T cell-tumor cell contact. It has long been known that cytotoxic T cells produce, among many other cytokines, also high level of IFNy [28, 29]. One of the most common recruitment axes for peripheral T cells into tumor involves this cytokine [30]. Quantification of chemokines levels in the supernatant from PBMCs derived CD8+ T cells co-cultured with WSU DLCL2 cells, revealed that, among other chemokines and cytokines, IFNy increased over time after CD20-TCB treatment, as compared to the untreated condition, reaching the peak of INFY levels $72 \mathrm{~h}$ post treatment (Fig. 5a). In the same settings, we indeed observed an increased proportion of IFNy $\mathrm{CD}^{+} \mathrm{T}$, as compared to the untreated condition, starting from $48 \mathrm{~h}$ post treatment (Fig. 5b). These data support the hypothesis that CD20-TCB first leads to stable synapses formation, that mediate direct tumor cytotoxicity and cytokine and chemokines production which leads to additional effects of CD20-TCB. Histology analysis of IFNy levels in subcutaneous tumors, despite heterogeneity of the samples, revealed a trend $(p=0.057)$ in higher amount of IFNy levels, of around 30 fold, $24 \mathrm{~h}$ post second injection of CD20-TCB, as compared to the untreated group (Fig. Supplementary 5a). It is well established that local IFNy production can mediate the recruitment of $\mathrm{CXCR}^{+}$effector $\mathrm{T}$ cells to tumors [31]. The main chemokines involved in $\mathrm{CXCR} 3^{+} \mathrm{T}$ cell recruitment to tumors are CXCL9, CXCL10 and CXCL11 [32]. In order to assess whether IFNy sustains CXCL9, CXCL10 and CXCL11 production in our settings, we treated WSU DLCL2 cells with decreasing doses of recombinant IFNy in vitro and then measured the abundance of these chemokines in the supernatant. Our analysis revealed that IFNy induces a selective and significant expression of CXCL10 in tumour cells(Fig. 5c). In line with this, CD20-TCB treatment of human T cell-WSU DLCL2 co-cultures leads to increased levels of many cytokines and chemokines including CXCL10, most likely by both tumor cells and T cells (Fig. 5d and data not shown). Based on the increase in CXCL10 expression upon IFNY or CD20-TCB treatment that we have observed, we then tested CXCL10 amount in the supernatant obtained from the co-culture of human PBMCs-derived CD8 ${ }^{+}$T cells with WSU DLCL2 cells at $24 \mathrm{~h}, 48 \mathrm{~h}$ and $72 \mathrm{~h}$ post CD20-TCB treatment. Our analysis revealed that CD20-TCB leads to increased CXCL10 secretion overtime that reaches the peak at $72 \mathrm{~h}$ post treatment, as previously observed for IFNy (Fig. 5e), strongly suggesting a direct correlation between the two mechanisms. In addition, tumor tissue analysis by histology revealed the same trend of increased CXCL10 expression (Fig. supplementary 5b) in mice treated with CD20-TCB 
bioRxiv preprint doi: https://doi org/10.1101/2020.10.09.332874; this version posted October 9,2020 . The copyright holder for this preprint (which was not certified by peer review) is the author/funder, who has granted bioRxiv a license to display the preprint in perpetuity. It is made available under aCC-BY 4.0 International license.

CD20-TCB induces IFNy/CXCL10-dependent T cell recruitment.

as compared to vehicle (increase of about 22 fold). In order to prove the role of IFNy in the recruitment of peripheral T cells, we pre-treated WSU DLCL2 with IFNy before intradermal injection, and imaged the tumors 72 hours later (supplementary video 24). Our analysis revealed an increased recruitment of peripheral blood T cells (orange) by IFNy pre-treated tumors, as compared to CD20-TCB (supplementary video 23) or vehicle (supplementary video 22) treated tumors. Moreover, analysis of T cell dynamics rules out the hypothesis that the recruitment is due to an increased activity of the resident $T$ cells (pink) as a consequence of IFNy pre-treatment (Fig. Supplementary 5c). This finding suggests that CD20-TCBmediated peripheral T cell recruitment in vivo might indeed involve factors released by tumor cells stimulated by T cell-produced IFNY.

To prove the role of IFNy and CXCL10 in T cell recruitment, we performed an experiment comparing skinfold chamber tumors pre-treated or not with IFNy, tumors treated with CD20-TCB, and tumors in which the treatment with CD20-TCB was followed by intravenous injection of alFNy or $\alpha \mathrm{CXCL} 10$ blocking antibodies. We then imaged the tumors 72 hours post therapy (Fig. 5f), and we counted the peripheral blood T cells (orange) recruited into each tumor (Fig. $\mathbf{5 g}$ ). In tumors that had been previously treated with IFNy, we could see a tendency of an increase in the number of peripheral blood T cells with a maximum of 42 peripheral blood $\mathrm{T}$ cells per $\mathrm{mm}^{2}$, although the recruitment was significantly higher in CD20-TCB-treated tumors, with a maximum of 148 peripheral blood $\mathrm{T}$ cells per $\mathrm{mm}^{2}$. The presence of either blocking antibody against CXCL10 or IFNy was able to significantly reduce peripheral T cell recruitment to a maximum of $5-10$ peripheral blood T cells per $\mathrm{mm}^{2}$ (Fig. $\mathbf{5 g}$ ). This finding supports the hypothesis that, upon treatment with CD20-TCB, resident T cells start killing the tumor, increasing the inflammatory cytokines, such as IFNY, in the microenvironment. This in turn induces tumor cells and T cells to secrete CXCL10, mediating the recruitment of $\mathrm{CXCR} 3^{+} \mathrm{T}$ cells from the periphery. As previously stated, the amount of tumor resident $\mathrm{T}$ cells impacts on the capacity to induce peripheral T cell recruitment upon treatment (Fig. $\mathbf{4 h - i ) . ~ I n ~ l i n e ~ w i t h ~ t h i s ~}$ we observed that decreasing the number of T cells in co-culture with WSU DLCL2 cells, leads to decreased amount of IFNy and CXCL10 secretion (Fig. supplementary $\mathbf{5 d - e ) . ~ T o ~ f u r t h e r ~ v a l i d a t e ~ t h e ~ i m p o r t a n c e ~ o f ~}$ this part of CD20-TCB MoA, we performed an in vivo efficacy experiment by subcutaneously injecting WSU DLCL2 cells, and treating established tumors with vehicle, CD20-TCB, or CD20-TCB in combination with aCXCL10 or alFNy blocking antibody (Fig. 6a). All treated groups were able to mediate tumor growth control 
CD20-TCB induces IFNY/CXCL10-dependent T cell recruitment.

and tumor regression, with CD20-TCB alone being able to almost eradicate the tumor by day 38 post therapy. The blocking of CXCL10 and IFNy was able to slightly reduce the anti-tumor effect of CD20-TCB, suggesting that their inhibition might be able to at least partially block $\mathrm{T}$ cell recruitment to the tumor. This was confirmed by histology examination whereby tumors treated with CD20-TCB showed a homogeneous and strong infiltration of $\mathrm{CD}^{+} \mathrm{T}$ cells, while treatment with either aCXCL10 or alFNy was able to partially reduce intra-tumor $\mathrm{T}$ cell infiltration (Fig. $\mathbf{6 b}, \mathbf{6 c}$ ). The tumors in the different groups displayed a high variability in size and infiltration; however, when investigating the correlation between tumor infiltration and tumor volume at termination, a significant inverse correlation was observed, with higher infiltration correlating with a stronger efficacy of CD20-TCB, thus a smaller tumor volume (Fig. 6d). Overall, these data show that CD20-TCB treatment is efficacious in mediating tumor infiltration and subsequent cytotoxicity. Moreover, we identified the IFNY-CXCL10 axis as being one of the drivers of TCB-mediated T cell infiltration in tumors, whereby IFNy released by activated T cells induces CXCL10 secretion, which in turns attracts CXCR3-expressing T cells into the tumor sites. Furthermore, we could show a strong correlation between infiltration and tumor shrinkage, regardless of the therapy regimen. 
bioRxiv preprint doi: https://doi.org/10.1101/2020.10.09.332874; this version posted October 9,2020 . The copyright holder for this preprint (which was not certified by peer review) is the author/funder, who has granted bioRxiv a license to display the preprint in perpetuity. It is made available under aCC-BY 4.0 International license.

CD20-TCB induces IFNY/CXCL10-dependent T cell recruitment.

\section{Discussion}

Redirecting T cells to hematological malignancies using bispecific antibodies is an attractive strategy to improve clinical outcome in addition to standard of care treatments. CD20-TCB (also known as RG6026 or glofitamab) is one of such examples showing remarkable benefits for relapsed and refractory DLBCL patients $[4,12,13,33]$. Like other bispecific antibodies, CD20-TCB activates $T$ cells by selectively

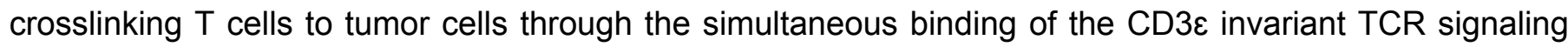
component and a tumor antigen (TA), specifically CD20 [34]. Using the aggressive DLBCL xenograft model (WSU DLCL2) and preclinical animal models of stem cell humanized (HSC) NSG mice[33], we have previously reported the mechanisms leading to CD20-TCB mediated in vitro tumor cell killing and its efficacy in vivo [3]. In this work, we had found that CD20-TCB can mediate cross-linking of T cells to tumor cells which correlated with CD20-TCB localization at the synaptic area [3], but information on the impact of the TCB mediated synapse quality (speed, contact length, area of contact, etc...) on the functional outcome (killing, recruitment, cytokine release, etc...) were still missing. One hypothesis arising from those findings was that CD20-TCB MoA, similar to TCR mediated interaction, could facilitate the formation of stable immunological synapses between T cells and tumor cells, whose stability and quality would impact $\mathrm{T}$ cell activation, cytotoxicity and cytokine release, as demonstrated in the context of TCR-mediated immune synapses [35]. To address this, we took advantage of the lower efficacy of CD20-TCB to induce T cell killing of OCl-Ly18 target tumor cells (as compared to WSU DLCL2). We realized that lower killing ability correlated with differential motility of T cells in culture with tumor cells. T cells in contact with OCI-Ly18 showed a lower contact area with tumor cells and increased speed as compared to T cells cultured with WSU DLCL2. These data supported our hypothesis that CD20-TCB affects the formation of T cells-tumor cells synapses. One of the major components of the immune synapsis is the integrin LFA-1 [15], which has been shown to be upregulated on canonical T cells surface after CD20-TCB crosslinking [3]. Among the multiple factors involved in synapse formation, the integrin LFA-1 is required for the stabilization and structural organization of the immunological synapse, by binding to its ligand ICAM-1 on target cells [36]. By directly visualizing LFA-1 using confocal microscopy, we observed that LFA-1 localizes at the synapse site between tumor and T cells. In addition, by selectively blocking LFA-1, we impaired the killing capacity of T cells stimulated by low-dose (but not high dose) of CD20-TCB. Because T cell killing was not impaired by blocking canonical 
bioRxiv preprint doi: https://doi.org/10.1101/2020.10.09.332874; this version posted October 9,2020 . The copyright holder for this preprint

(which was not certified by peer review) is the author/funder, who has granted bioRxiv a license to display the preprint in perpetuity. It is made available under aCC-BY 4.0 International license.

CD20-TCB induces IFNy/CXCL10-dependent T cell recruitment.

apoptosis ligands such as FAS-L, we concluded that CD20-TCB-induced synapse formation is very important for its activity $[37,38]$. This is not surprising as the synapse area is a critical parameter for effector T cells activity, including release of effector cytokines, effector granules and death inducing ligands [39]. In addition, inhibitory pathways such as PD-1 and CTLA-4 are recruited at the synapse area and may interfere with synapse formation [40, 41]. Altogether, our data suggest that CD20-TCB improves T cell killing of tumor cells by stabilizing synapses. T cells-tumor cells synapse stabilization may also interfere with negative feedback loops and thereby CD20-TCB could have synergistic effects with checkpoint inhibitors in the context of cancer immuno-therapy. The efficacy of CD20-TCB combination with PD-L1 inhibition by Atezolizumab is currently being investigated in a Phase lb study (NCT03533283).

Given the importance of the synapse formation by CD20-TCB to mediate activity, we explored innovative models to perform dynamic in vivo imaging [22, 42]. Indeed, evaluation of synapse formation between human T cells and tumor in vivo using clinical lead molecules has been a long lasting question that was never optimally addressed due to lack of a proper model. One of the main reasons of failure is due to the xenoreaction of human cells towards mouse tissues and to the alloreaction of T cells towards the tumor [18, $25,26]$. These two reactions can strongly affect the $T$ cell behavior possibly masking any additional effect of the studied therapy. We hereby present an experimental design that aims at reducing xenoreaction thus allowing the study of the T cell-tumor cell dynamics in response to immunotherapy. We show here that GvHD does not occur in stem cell humanized mice (HSC-NSG mice), as opposed to human PBMC transfer into NSG mice (PBMC-NSG mice). The profile of leukocytes derived from HSC-NSG mice more closely resembles the profile of human blood-derived cells than the profile of leukocytes derived from mice recipients of PBMC transfer, with lower frequency of activated and higher frequency of naïve conventional T cells. Furthermore, T cells derived from the spleen of HSC-NSG humanized mice where less reactive to the tumor environment in the absence of therapy when compared to T cells derived from human PBMCs. It was indeed possible to observe a difference between treated and untreated tumors in terms of $\mathrm{T}$ cell response, indicating that the transfer of humanized mice-derived T cells in the context of NSG mice (HSCNSG-NSG) is a good model to analyze T cell dynamics in tumors, minimizing xenoreaction. The control group for the alloreaction towards human tumors that might still occur, was a vehicle group injected with the same T cell batch. One limitation of this model, as compared to syngeneic models [43] or other humanized 
bioRxiv preprint doi: https://doi.org/10.1101/202010.09.332874; this version posted October 9,2020 . The copyright holder for this preprint (which was not certified by peer review) is the author/funder, who has granted bioRxiv a license to display the preprint in perpetuity. It is made available under aCC-BY 4.0 International license.

CD20-TCB induces IFNy/CXCL10-dependent T cell recruitment.

mouse models $[25,26]$, is that the most represented functional cells are conventional CD4 and CD8 T cells [3] and therefore the conclusion on the mode of action of CD20-TCB mostly refers to those subsets. Treg $\mathrm{CD}^{+}$cells which are very important in controlling tumor growth and response to immunotherapies [44] are poorly represented. To verify whether these findings also affect Treg, the platform here described could be adapted using humanized models with higher degree of Treg frequency [45].

Our innovative model allowed us to evaluate in vivo the direct effect of CD20-TCB on T cell dynamics and synapse formation in the tumor upon intravenous administration, correlating pharmacokinetics with the pharmacodynamic changes in the tumor defined as synapse formation between human $\mathrm{T}$ cells and tumor target cells. Despite CD20-TCB high molecular weight (194.342 kDa), we found that T cells start interacting and forming synapses with the tumor cells as early as 30 minutes after intravenous injection of CD20-TCB. In addition, the analysis of the dynamics of recruited T cells at 72 hours after therapy, indicate that CD20TCB is still available in the tumor and it can still mediate interaction between tumor and T cells. We here presented a novel imaging platform, flexible enough to be applied to analyze additional leukocyte subpopulations in the context of T cell bi-specific engagers such as TCB. This could help define the time a given compound reaches the tumor site and activates a response, making it possible to evaluate functional pharmacokinetics and the duration of the effect of the drug after treatment, possibly applying this knowledge to the design of treatment schedules for preclinical and clinical studies. Besides its cross-linking and direct cytotoxicity effect, it has been observed that CD20-TCB, as well as other T cell bispecific antibodies, lead to an increased number of intra-tumor CD3 T cells when compared to vehicle, probably as a result of CD20TCB-induced T cell proliferation and cytokine production $[3,43,46]$. By histological analysis of tumors treated with CD20-TCB, we revealed a significant increase of intra-tumor proliferating CD3 T cells, as compared to the vehicle. In addition, we observed increased numbers of $\mathrm{CXCR} 3^{+} \mathrm{CD} 3^{+} \mathrm{T}$ cells within the tumor, suggesting a possible CD20-TCB-dependent recruitment of peripheral activated and memory T cells, in line with previous observation using TCR mediated T cell activation $[47,48]$. A previous study in a breast cancer mouse model, using a surrogate molecule, showed that HER2-TDB leads to increased numbers of $\mathrm{CXCR}^{+} \mathrm{CD}^{+}$murine $\mathrm{T}$ cells within the tumor [43], suggesting that this mechanism might be shared among different $\mathrm{T}$ cell engagers. However, it still remains to be addressed whether human $\mathrm{T}$ cells share a similar 
bioRxiv preprint doi: https://doi.org/10.1101/2020.10.09.332874; this version posted October 9,2020 . The copyright holder for this preprint

(which was not certified by peer review) is the author/funder, who has granted bioRxiv a license to display the preprint in perpetuity. It is made available under aCC-BY 4.0 International license.

CD20-TCB induces IFNy/CXCL10-dependent T cell recruitment.

behavior with murine T cells. Our data suggest indeed that also human T cells use the axis IFNg-CXCL10CXCR3 as one of recruitment mechanism of peripheral T cell into tumor.

An important observation supporting the elucidation of recruitment of human $\mathrm{T}$ cells into the tumor is that the amount of peripheral T cells recruited to the tumor correlates with the number of resident T cells. Indeed, 72 hours post therapy, the absence of resident $T$ cells in the tumor had no effect on peripheral $T$ cell recruitment, resulting in comparable effects to those observed in vehicle. By contrast, even a low starting ratio of T cells-tumor cells (1:100 and 1:10) was sufficient to mediate a detectable infiltration of peripheral blood T cells when compared to vehicle. Noteworthy, increasing the number of resident T cells to a $1: 1$ ratio to tumor cells further increased the number of recruited peripheral blood T cells. This finding supports the idea that CD20-TCB ability to engage the few resident T cells present in tumor is important to mount the intra-tumor inflammation and lead to anti-tumor efficacy and plays an important role in transforming desert tumor to tumor infiltrated by $T$ cells. $[43,46,49]$.

As previously shown, some of the chemokines involved in T cell recruitment to tumors are the Chemokine (C-X-C motif) Ligands (CXCL)-9 and 10 [32]. These are induced by local TNFa and IFNy cytokine production, and can mediate the recruitment of Chemokine Receptor (CXCR)-3-positive effector T cells to tumors [31]. Different studies demonstrated that $\mathrm{CXCR} 3^{+} \mathrm{T}$ cell recruitment is regulated by IFNy [50]. In our study we demonstrated that CD20-TCB leads to increased IFNy secretion by activated T cells. Among the CXCR3 binding chemokines produced, we focused on the increase of IFNY and CXCL10, after CD20-TCB treatment. By using blocking antibodies in vivo, we confirmed that the IFNY-CXCL10-CXCR3 axis is involved in the recruitment of peripheral blood human T cells upon CD20-TCB treatment. Despite the strong impact on T cell recruitment, we observed a mild effect of CXCL10 and IFNy blockade in impairing the efficacy of CD20-TCB in a model of B cell lymphoma in humanized mice. In this regard we could argue that CXCL10 or IFNy blockade is not sufficient to completely abrogate the efficacy of CD20-TCB mostly because of the contribution of different pathways, such as TNFa induced CXCL9 and CXCL11 [51] in the recruitment of $\mathrm{CXCR}^{+} \mathrm{T}$ cells and because of the strong induction of proliferation induced by CD20-TCB. However, $\mathrm{T}$ cell recruitment strongly correlates with efficacy demonstrating the importance of recruitment to the TCB MoA. Additional studies are needed in order to identify all the mechanisms involved in human $\mathrm{T}$ cell recruitment and how to use them to control tumor growth and potentially develop new immune-therapeutics. 
CD20-TCB induces IFNy/CXCL10-dependent T cell recruitment.

In conclusion, we correlate the quality of the synapse mediated by the T cell bispecific antibody CD20-TCB (RO7082859) with the ability to kill target cells and promote T cell recruitment. We used an innovative DLBCL in vivo imaging model using last generation humanized mice that allowed the in vivo visualization of the human immune system. We observed that CD20-TCB mediated lymphoma/T cell can trigger the production of IFNy, which in turn leads to production of CXCL10. This pathway is responsible for increasing $\mathrm{T}$ cell retention and recruitment within the tumor microenvironment, supporting the efficacy of the therapy by turning a not-infiltrated tumor into a highly inflamed one. This dataset supports the idea of using such therapeutic classes in the clinics also for tumors which that show poor T cell infiltration.

\section{Compliance with Ethical Standard}

All the experiments were performed according to committed guidelines (GV-Solas; Felasa; TierschG). Experimental study protocol was reviewed and approved by local government (ZH193/2014 and ZH222-17) and by the Ethical Committee of the Roche Innovation Centre of Zurich.

\section{Acknowledgements}

The authors wish to thank all the Roche Innovation Centre Zurich, the colleagues from pREDi for all their support as well as the protein Engineer group especially Claudia Ferrara Koller, Anne FreimoserGrundschober and Martina Carola Birk.

\section{Conflict of interest}

All authors of this manuscript are employees of Roche. 
bioRxiv preprint doi: https://doi.org/10.1101/2020.10.09.332874; this version posted October 9,2020 . The copyright holder for this preprint (which was not certified by peer review) is the author/funder, who has granted bioRxiv a license to display the preprint in perpetuity. It is made available under aCC-BY 4.0 International license.

CD20-TCB induces IFNY/CXCL10-dependent T cell recruitment.

\section{References}

1. Teras LR, DeSantis CE, Cerhan JR, Morton LM, Jemal A, Flowers CR. 2016 US lymphoid malignancy statistics by World Health Organization subtypes. CA Cancer J Clin. 2016;66(6):443-59. Epub 2016/09/13. doi: 10.3322/caac.21357. PubMed PMID: 27618563.

2. Zhang J, Medeiros LJ, Young KH. Cancer Immunotherapy in Diffuse Large B-Cell Lymphoma. Front Oncol. 2018;8:351. Epub 2018/09/27. doi: 10.3389/fonc.2018.00351. PubMed PMID: 30250823; PubMed Central PMCID: PMCPMC6140403.

3. Bacac M, Colombetti S, Herter S, Sam J, Perro M, Chen S, et al. CD20-TCB with Obinutuzumab Pretreatment as Next-Generation Treatment of Hematologic Malignancies. Clin Cancer Res. 2018;24(19):4785-97. Epub 2018/05/03. doi: 10.1158/1078-0432.CCR-18-0455. PubMed PMID: 29716920. 4. Hutchings M, lacoboni G, Morschhauser F, Offner F, Sureda A, Salles GA, et al. CD20-Tcb (RG6026), a Novel "2:1" Format T-Cell-Engaging Bispecific Antibody, Induces Complete Remissions in Relapsed/Refractory B-Cell Non-Hodgkin's Lymphoma: Preliminary Results from a Phase I First in Human Trial. Blood. 2018;132(Suppl 1):226-. doi: 10.1182/blood-2018-99-110207.

5. Noone AM HN, Krapcho M, Miller D, Brest A, Yu M, Ruhl J, Tatalovich Z, Mariotto A, Lewis DR, Chen HS, Feuer EJ, Cronin KA (eds). SEER Cancer Statistics Review, 1975-2015 2008. Available from: https://seer.cancer.gov/csr/1975 2015/.

6. Cultrera JL, Dalia SM. Diffuse large B-cell lymphoma: current strategies and future directions. Cancer Control. 2012;19(3):204-13. Epub 2012/06/20. doi: 10.1177/107327481201900305. PubMed PMID: 22710896.

7. Pierpont TM, Limper CB, Richards KL. Past, Present, and Future of Rituximab-The World's First Oncology Monoclonal Antibody Therapy. Front Oncol. 2018;8:163. doi: 10.3389/fonc.2018.00163. PubMed PMID: 29915719; PubMed Central PMCID: PMC5994406.

8. Caimi PF, Hill BT, Hsi ED, Smith MR. Clinical approach to diffuse large B cell lymphoma. Blood Rev. 2016;30(6):477-91. Epub 2016/09/07. doi: 10.1016/j.blre.2016.06.003. PubMed PMID: 27596109.

9. Bacac M, Klein C, Umana P. CEA TCB: A novel head-to-tail 2:1 T cell bispecific antibody for treatment of CEA-positive solid tumors. Oncoimmunology. 2016;5(8):e1203498. Epub 2016/09/14. doi: 10.1080/2162402X.2016.1203498. PubMed PMID: 27622073; PubMed Central PMCID: PMCPMC5007959.

10. Hutchings M, Gritti G, Sureda A, Terol MJ, Dyer MJ, lacoboni G, et al. CD20-TCB, a Novel T-CellEngaging Bispecific Antibody, Can be Safely Combined with the Anti-PD-L1 Antibody Atezolizumab in Relapsed or Refractory B-Cell Non-Hodgkin Lymphoma. Blood. 2019;134(Supplement_1):2871-. doi: 10.1182/blood-2019-123978.

11. Hutchings M, lacoboni G, Morschhauser F, Offner F, Sureda A, Salles GA, et al. CD20-Tcb (RG6026), a Novel "2:1" Format T-Cell-Engaging Bispecific Antibody, Induces Complete Remissions in Relapsed/Refractory B-Cell Non-Hodgkin's Lymphoma: Preliminary Results from a Phase I First in Human Trial. Blood. 2018;132(Supplement 1):226-. doi: 10.1182/blood-2018-99-110207.

12. Morschhauser F, Carlo-Stella C, Offner F, Salles GA, Hutchings M, lacoboni G, et al. Dual CD20Targeted Therapy With Concurrent CD20-TCB and Obinutuzumab Shows Highly Promising Clinical Activity and Manageable Safety in Relapsed or Refractory B-Cell Non-Hodgkin Lymphoma: Preliminary Results From a Phase Ib Trial. Blood. 2019;134(Supplement_1):1584-. doi: 10.1182/blood-2019-123949.

13. Bröske A-ME, James I, Belousov A, Gomez E, Canamero M, Ooi C-H, et al. CD20-TCB, a Novel TCell-Engaging Bispecific Antibody, Induces T-Cell-Mediated Killing in Relapsed or Refractory Non-Hodgkin Lymphoma: Biomarker Results From a Phase I Dose-Escalation Trial. Blood. 2019;134(Supplement_1):5319-. doi: 10.1182/blood-2019-123979.

14. Chen DS, Mellman I. Elements of cancer immunity and the cancer-immune set point. Nature. 2017;541(7637):321-30. doi: 10.1038/nature21349. PubMed PMID: 28102259.

15. Lanitis E, Dangaj D, Irving M, Coukos G. Mechanisms regulating T-cell infiltration and activity in solid tumors. Ann Oncol. 2017;28(suppl_12):xii18-xii32. doi: 10.1093/annonc/mdx238. PubMed PMID: 29045511.

16. Chen DS, Mellman I. Oncology meets immunology: the cancer-immunity cycle. Immunity. 2013;39(1):1-10. doi: 10.1016/j.immuni.2013.07.012. PubMed PMID: 23890059.

17. Bacac M, Fauti T, Sam J, Colombetti S, Weinzierl T, Ouaret D, et al. A Novel Carcinoembryonic Antigen T-Cell Bispecific Antibody (CEA TCB) for the Treatment of Solid Tumors. Clin Cancer Res. 2016;22(13):3286-97. Epub 2016/02/11. doi: 10.1158/1078-0432.CCR-15-1696. PubMed PMID: 26861458. 
bioRxiv preprint doi: https://doi.org/10.1101/2020.10.09.332874; this version posted October 9,2020 . The copyright holder for this preprint (which was not certified by peer review) is the author/funder, who has granted bioRxiv a license to display the preprint in perpetuity. It is made available under aCC-BY 4.0 International license.

CD20-TCB induces IFNY/CXCL10-dependent T cell recruitment.

18. Lehmann S, Perera R, Grimm HP, Sam J, Colombetti S, Fauti T, et al. In Vivo Fluorescence Imaging of the Activity of CEA TCB, a Novel T-Cell Bispecific Antibody, Reveals Highly Specific Tumor Targeting and Fast Induction of T-Cell-Mediated Tumor Killing. Clin Cancer Res. 2016;22(17):4417-27. doi: 10.1158/1078-0432.CCR-15-2622. PubMed PMID: 27117182.

19. Matheu MP, Cahalan MD, Parker I. Immunoimaging: studying immune system dynamics using twophoton microscopy. Cold Spring Harb Protoc. 2011;2011(2):pdb top99. doi: 10.1101/pdb.top99. PubMed PMID: 21285279.

20. Mrass P, Takano H, Ng LG, Daxini S, Lasaro MO, Iparraguirre A, et al. Random migration precedes stable target cell interactions of tumor-infiltrating T cells. J Exp Med. 2006;203(12):2749-61. doi: 10.1084/jem.20060710. PubMed PMID: 17116735; PubMed Central PMCID: PMC2118164.

21. Breart B, Lemaitre F, Celli S, Bousso P. Two-photon imaging of intratumoral CD8+ T cell cytotoxic activity during adoptive $T$ cell therapy in mice. J Clin Invest. 2008;118(4):1390-7. doi: 10.1172/JCI34388. PubMed PMID: 18357341; PubMed Central PMCID: PMC2268880.

22. Koehl GE, Gaumann A, Geissler EK. Intravital microscopy of tumor angiogenesis and regression in the dorsal skin fold chamber: mechanistic insights and preclinical testing of therapeutic strategies. Clin Exp Metastasis. 2009;26(4):329-44. doi: 10.1007/s10585-008-9234-7. PubMed PMID: 19190882.

23. Dieckmann NM, Frazer GL, Asano Y, Stinchcombe JC, Griffiths GM. The cytotoxic T lymphocyte immune synapse at a glance. J Cell Sci. 2016;129(15):2881-6. Epub 2016/08/10. doi: 10.1242/jcs.186205. PubMed PMID: 27505426.

24. Wabnitz GH, Lohneis P, Kirchgessner H, Jahraus B, Gottwald S, Konstandin M, et al. Sustained LFA-1 cluster formation in the immune synapse requires the combined activities of L-plastin and calmodulin. Eur J Immunol. 2010;40(9):2437-49. Epub 2010/08/05. doi: 10.1002/eji.201040345. PubMed PMID: 20683899.

25. Ehx G, Somja J, Warnatz HJ, Ritacco C, Hannon M, Delens L, et al. Xenogeneic Graft-Versus-Host Disease in Humanized NSG and NSG-HLA-A2/HHD Mice. Front Immunol. 2018;9:1943. Epub 2018/09/15. doi: 10.3389/fimmu.2018.01943. PubMed PMID: 30214443; PubMed Central PMCID: PMCPMC6125392.

26. Shultz LD, Ishikawa F, Greiner DL. Humanized mice in translational biomedical research. Nat Rev Immunol. 2007;7(2):118-30. doi: 10.1038/nri2017. PubMed PMID: 17259968.

27. Nagarsheth N, Wicha MS, Zou W. Chemokines in the cancer microenvironment and their relevance in cancer immunotherapy. Nat Rev Immunol. 2017;17(9):559-72. Epub 2017/05/31. doi: 10.1038/nri.2017.49. PubMed PMID: 28555670; PubMed Central PMCID: PMCPMC5731833.

28. Wheelock EF. Interferon-Like Virus-Inhibitor Induced in Human Leukocytes by Phytohemagglutinin. Science. 1965;149(3681):310-1. doi: 10.1126/science.149.3681.310. PubMed PMID: 17838106.

29. Green JA, Cooperband SR, Kibrick S. Immune specific induction of interferon production in cultures of human blood lymphocytes. Science. 1969;164(3886):1415-7. PubMed PMID: 5783715.

30. Nakajima C, Mukai T, Yamaguchi N, Morimoto Y, Park WR, Iwasaki M, et al. Induction of the chemokine receptor CXCR3 on TCR-stimulated T cells: dependence on the release from persistent TCRtriggering and requirement for IFN-gamma stimulation. Eur J Immunol. 2002;32(6):1792-801. doi: 10.1002/1521-4141(200206)32:6<1792::AID-IMMU1792>3.0.CO;2-0. PubMed PMID: 12115663.

31. Bronger H, Singer J, Windmuller C, Reuning U, Zech D, Delbridge C, et al. CXCL9 and CXCL10 predict survival and are regulated by cyclooxygenase inhibition in advanced serous ovarian cancer. $\mathrm{Br} \mathrm{J}$ Cancer. 2016;115(5):553-63. doi: 10.1038/bjc.2016.172. PubMed PMID: 27490802; PubMed Central PMCID: PMC4997538.

32. Liu M, Guo S, Stiles JK. The emerging role of CXCL10 in cancer (Review). Oncol Lett. 2011;2(4):583-9. doi: 10.3892/ol.2011.300. PubMed PMID: 22848232; PubMed Central PMCID: PMC3406435.

33. Dickinson MJ, Morschhauser F, lacoboni G, Carlo-Stella C, Offner FC, Sureda A, et al. CD20-TCB (RG6026), A NOVEL “2:1" FORMAT T-CELL-ENGAGING BISPECIFIC ANTIBODY, INDUCES COMPLETE REMISSIONS IN RELAPSED/REFRACTORY B-CELL NON-HODGKIN'S LYMPHOMA. Hematological Oncology. 2019;37(S2):92-3. doi: 10.1002/hon.59_2629.

34. Huehls AM, Coupet TA, Sentman CL. Bispecific T-cell engagers for cancer immunotherapy. Immunol Cell Biol. 2015;93(3):290-6. Epub 2014/11/05. doi: 10.1038/icb.2014.93. PubMed PMID: 25367186; PubMed Central PMCID: PMCPMC4445461. 
bioRxiv preprint doi: https://doi.org/10.1101/2020.10.09.332874; this version posted October 9,2020 . The copyright holder for this preprint (which was not certified by peer review) is the author/funder, who has granted bioRxiv a license to display the preprint in perpetuity. It is made available under aCC-BY 4.0 International license.

CD20-TCB induces IFNy/CXCL10-dependent T cell recruitment.

35. Wurzer H, Hoffmann C, Al Absi A, Thomas C. Actin Cytoskeleton Straddling the Immunological Synapse between Cytotoxic Lymphocytes and Cancer Cells. Cells. 2019;8(5). Epub 2019/05/19. doi: 10.3390/cells8050463. PubMed PMID: 31100864; PubMed Central PMCID: PMCPMC6563383.

36. Graf B, Bushnell T, Miller J. LFA-1-mediated T cell costimulation through increased localization of TCR/class II complexes to the central supramolecular activation cluster and exclusion of CD45 from the immunological synapse. J Immunol. 2007;179(3):1616-24. Epub 2007/07/21. doi: 10.4049/jimmunol.179.3.1616. PubMed PMID: 17641028; PubMed Central PMCID: PMCPMC3993012.

37. Haas C, Krinner E, Brischwein K, Hoffmann P, Lutterbuse R, Schlereth B, et al. Mode of cytotoxic action of T cell-engaging BiTE antibody MT110. Immunobiology. 2009;214(6):441-53. Epub 2009/01/23. doi: 10.1016/j.imbio.2008.11.014. PubMed PMID: 19157637.

38. Loffler A, Kufer P, Lutterbuse R, Zettl F, Daniel PT, Schwenkenbecher JM, et al. A recombinant bispecific single-chain antibody, CD19 x CD3, induces rapid and high lymphoma-directed cytotoxicity by unstimulated T lymphocytes. Blood. 2000;95(6):2098-103. Epub 2000/03/09. PubMed PMID: 10706880.

39. Dustin ML. The immunological synapse. Cancer Immunol Res. 2014;2(11):1023-33. Epub 2014/11/05. doi: 10.1158/2326-6066.CIR-14-0161. PubMed PMID: 25367977; PubMed Central PMCID: PMCPMC4692051.

40. Yokosuka T, Takamatsu M, Kobayashi-Imanishi W, Hashimoto-Tane A, Azuma M, Saito T. Programmed cell death 1 forms negative costimulatory microclusters that directly inhibit $\mathrm{T}$ cell receptor signaling by recruiting phosphatase SHP2. J Exp Med. 2012;209(6):1201-17. Epub 2012/05/30. doi: 10.1084/jem.20112741. PubMed PMID: 22641383; PubMed Central PMCID: PMCPMC3371732.

41. Pentcheva-Hoang T, Egen JG, Wojnoonski K, Allison JP. B7-1 and B7-2 selectively recruit CTLA-4 and CD28 to the immunological synapse. Immunity. 2004;21(3):401-13. Epub 2004/09/11. doi: 10.1016/j.immuni.2004.06.017. PubMed PMID: 15357951.

42. Torcellan T, Stolp J, Chtanova T. In Vivo Imaging Sheds Light on Immune Cell Migration and Function in Cancer. Front Immunol. 2017;8:309. Epub 2017/04/07. doi: 10.3389/fimmu.2017.00309. PubMed PMID: 28382036; PubMed Central PMCID: PMCPMC5360706.

43. Li J, Ybarra R, Mak J, Herault A, De Almeida P, Arrazate A, et al. IFNgamma-induced Chemokines Are Required for CXCR3-mediated T-Cell Recruitment and Antitumor Efficacy of Anti-HER2/CD3 Bispecific Antibody. Clin Cancer Res. 2018;24(24):6447-58. Epub 2018/06/29. doi: 10.1158/1078-0432.CCR-181139. PubMed PMID: 29950350.

44. Josefowicz SZ, Lu LF, Rudensky AY. Regulatory T cells: mechanisms of differentiation and function. Annu Rev Immunol. 2012;30:531-64. Epub 2012/01/10. doi: 10.1146/annurev.immunol.25.022106.141623. PubMed PMID: 22224781; PubMed Central PMCID: PMCPMC6066374.

45. Hahn SA, Bellinghausen I, Trinschek B, Becker C. Translating Treg Therapy in Humanized Mice. Front Immunol. 2015;6:623. Epub 2015/12/24. doi: 10.3389/fimmu.2015.00623. PubMed PMID: 26697017; PubMed Central PMCID: PMCPMC4677486.

46. Goebeler ME, Bargou RC. T cell-engaging therapies - BiTEs and beyond. Nat Rev Clin Oncol. 2020. Epub 2020/04/04. doi: 10.1038/s41571-020-0347-5. PubMed PMID: 32242094.

47. Sallusto F, Kremmer E, Palermo B, Hoy A, Ponath P, Qin S, et al. Switch in chemokine receptor expression upon TCR stimulation reveals novel homing potential for recently activated T cells. Eur $\mathrm{J}$ Immunol. 1999;29(6):2037-45. Epub 1999/06/26. doi: 10.1002/(SICI)1521-4141(199906)29:06<2037::AIDIMMU2037>3.0.CO;2-V. PubMed PMID: 10382767.

48. Mikucki ME, Fisher DT, Matsuzaki J, Skitzki JJ, Gaulin NB, Muhitch JB, et al. Non-redundant requirement for CXCR3 signalling during tumoricidal T-cell trafficking across tumour vascular checkpoints. Nat Commun. 2015;6:7458. Epub 2015/06/26. doi: 10.1038/ncomms8458. PubMed PMID: 26109379; PubMed Central PMCID: PMCPMC4605273.

49. June $\mathrm{CH}$, O'Connor RS, Kawalekar OU, Ghassemi S, Milone MC. CAR T cell immunotherapy for human cancer. Science. 2018;359(6382):1361-5. Epub 2018/03/24. doi: 10.1126/science.aar6711. PubMed PMID: 29567707.

50. Metzemaekers M, Vanheule V, Janssens R, Struyf S, Proost P. Overview of the Mechanisms that May Contribute to the Non-Redundant Activities of Interferon-Inducible CXC Chemokine Receptor 3 Ligands. Front Immunol. 2017;8:1970. Epub 2018/01/31. doi: 10.3389/fimmu.2017.01970. PubMed PMID: 29379506 ; PubMed Central PMCID: PMCPMC5775283.

51. Tokunaga R, Zhang W, Naseem M, Puccini A, Berger MD, Soni S, et al. CXCL9, CXCL10, CXCL11/CXCR3 axis for immune activation - A target for novel cancer therapy. Cancer Treat Rev. 
bioRxiv preprint doi: https://doi.org/10.1101/2020.10.09.332874; this version posted October 9, 2020. The copyright holder for this preprint (which was not certified by peer review) is the author/funder, who has granted bioRxiv a license to display the preprint in perpetuity. It is made available under aCC-BY 4.0 International license.

CD20-TCB induces IFNY/CXCL10-dependent T cell recruitment.

2018;63:40-7. Epub 2017/12/06. doi: 10.1016/j.ctrv.2017.11.007. PubMed PMID: 29207310; PubMed Central PMCID: PMCPMC5801162. 
Fig.1 a

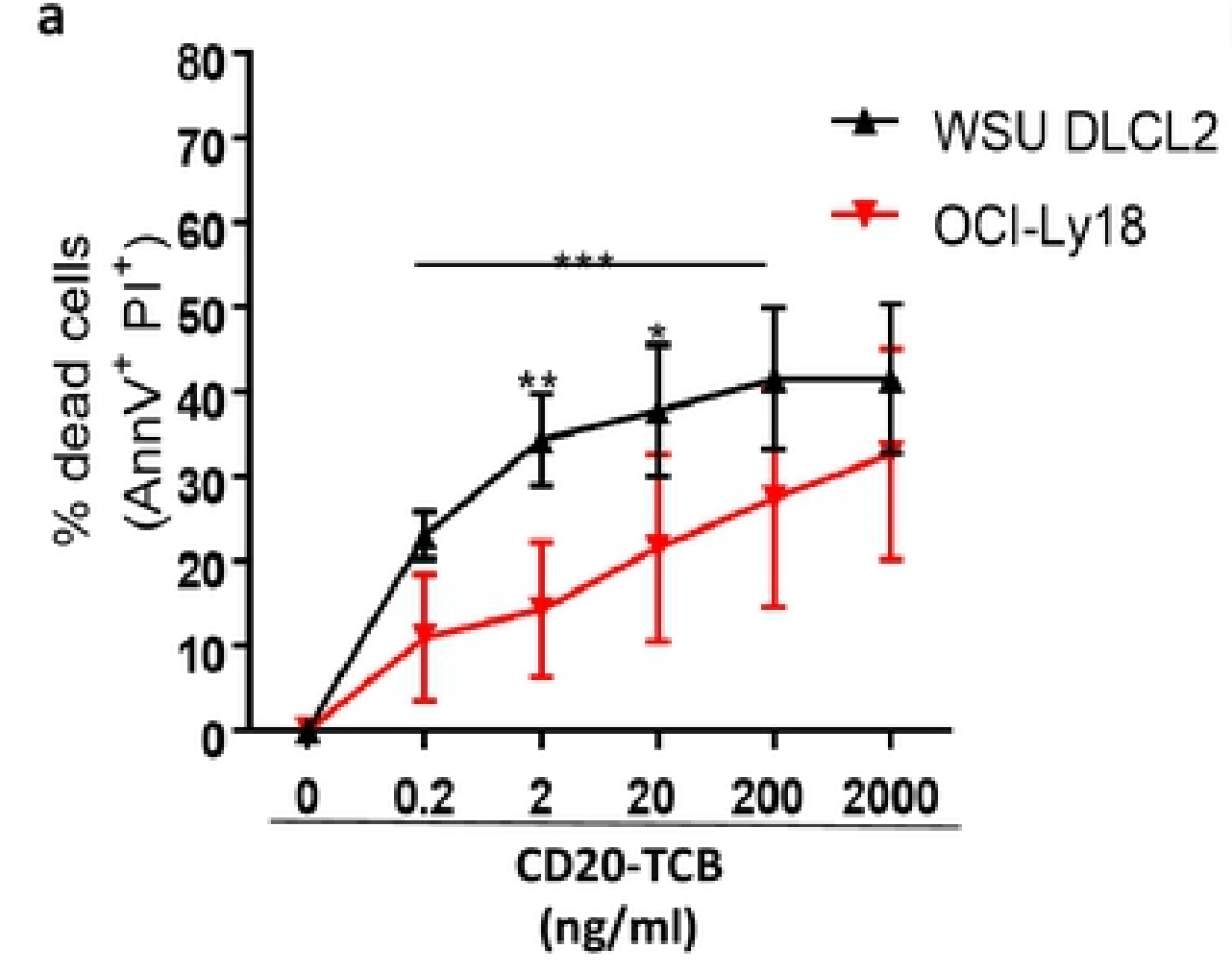

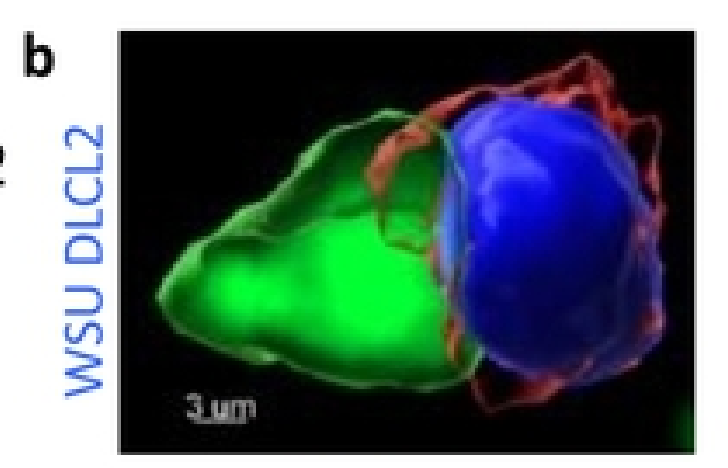

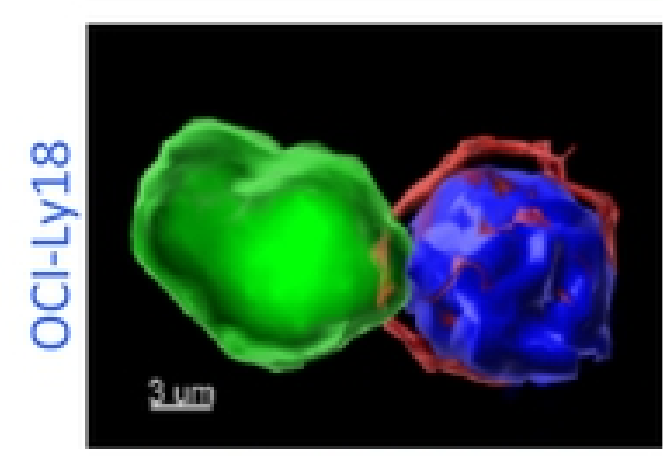

T cell CD20-TCB
C

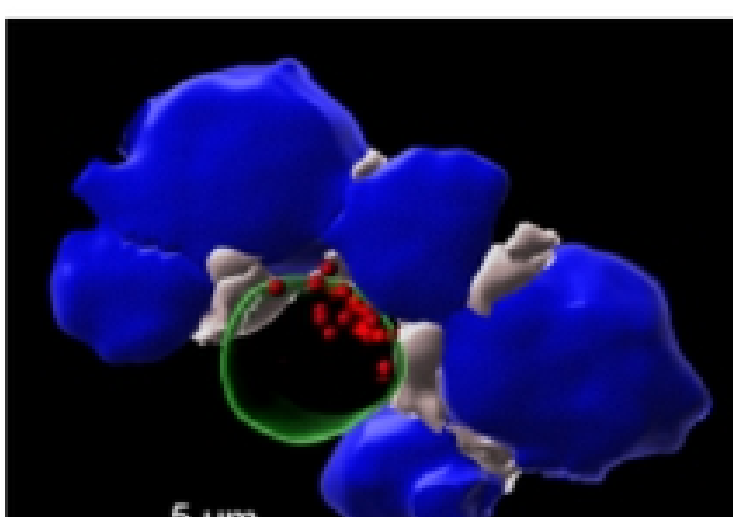

5 um

T cell

WSU DLCL2
CD20-TCB

Granzyme B d

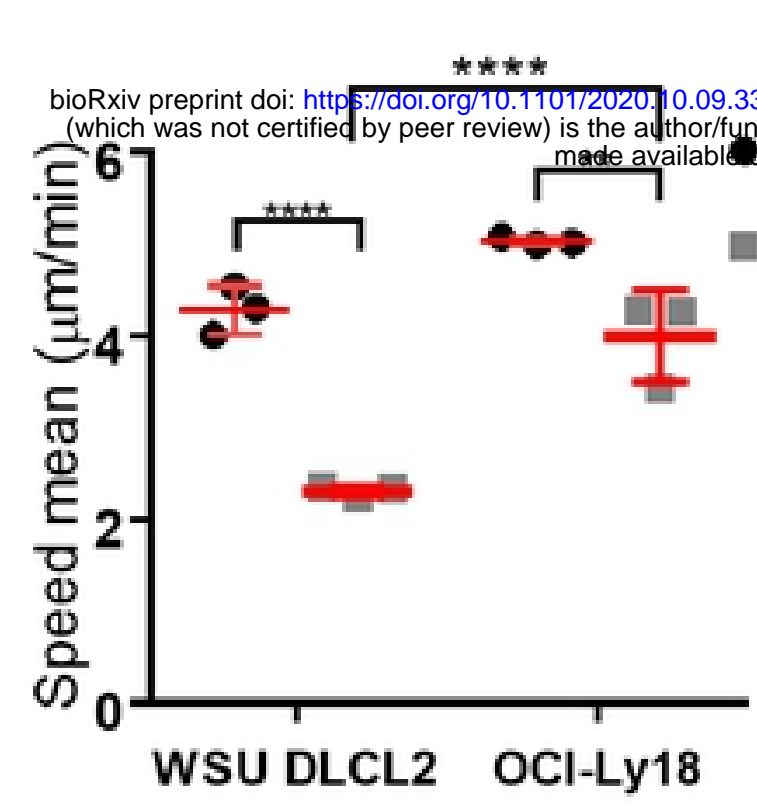

f

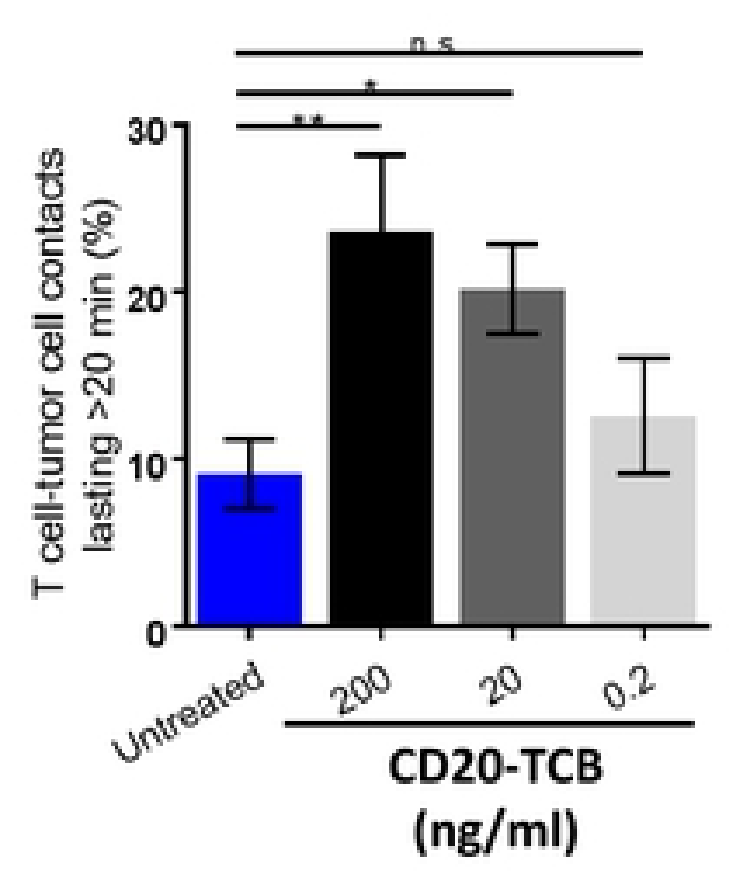

i

WSU DLCL2 F-Actin LFA-1

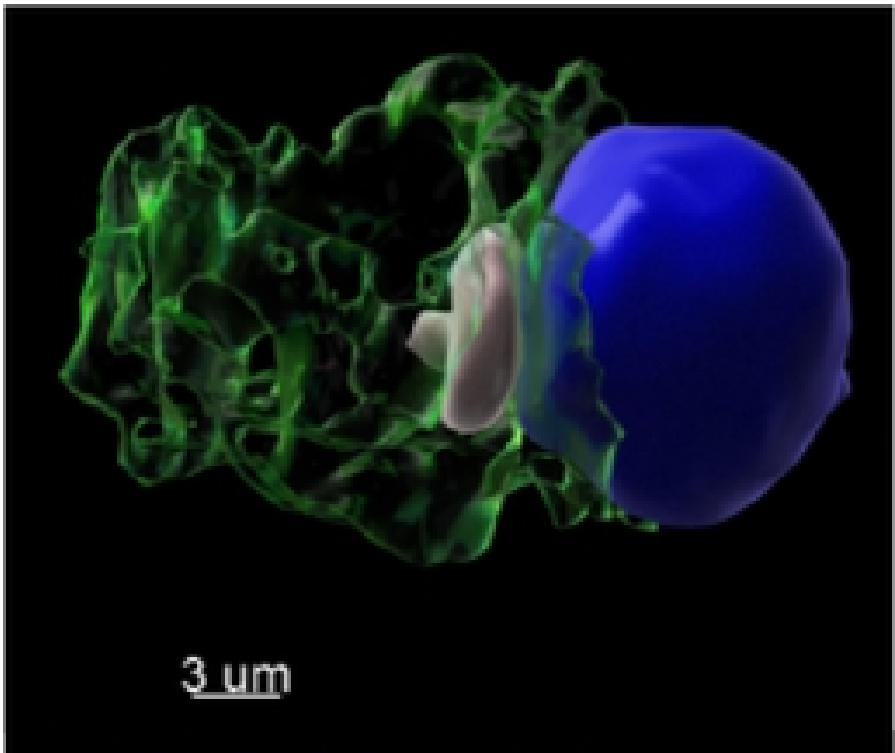

g

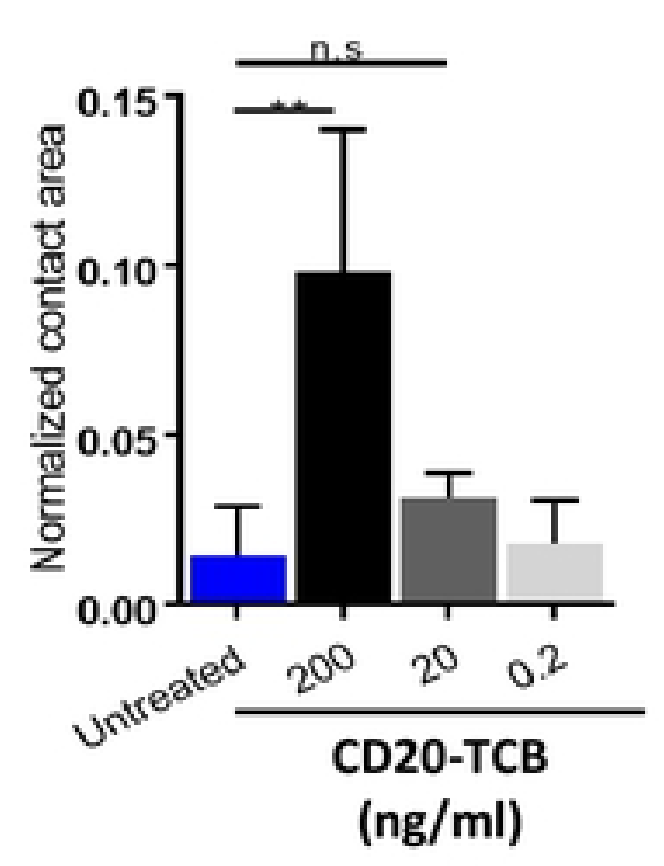

- Untreated

- CD20-TCB

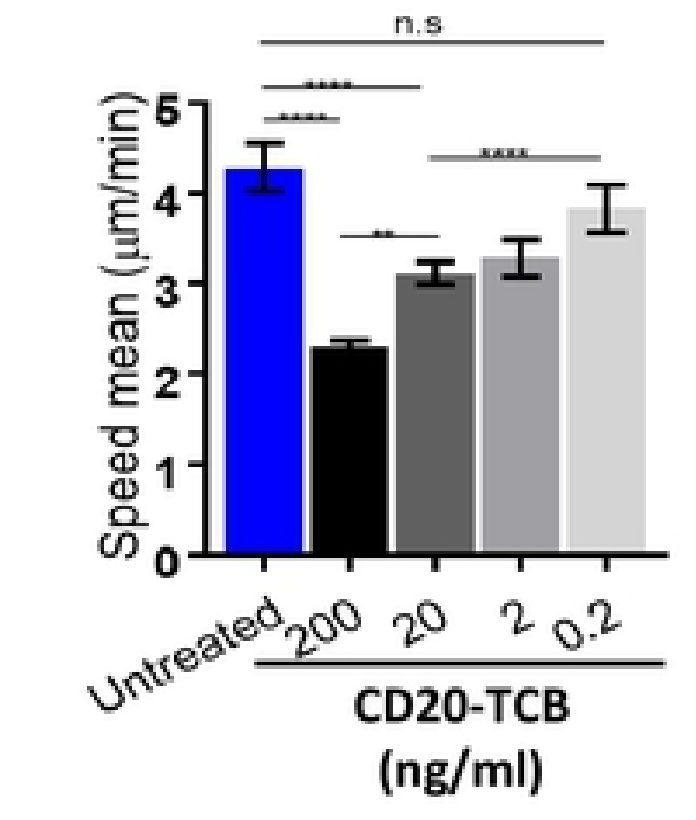

h

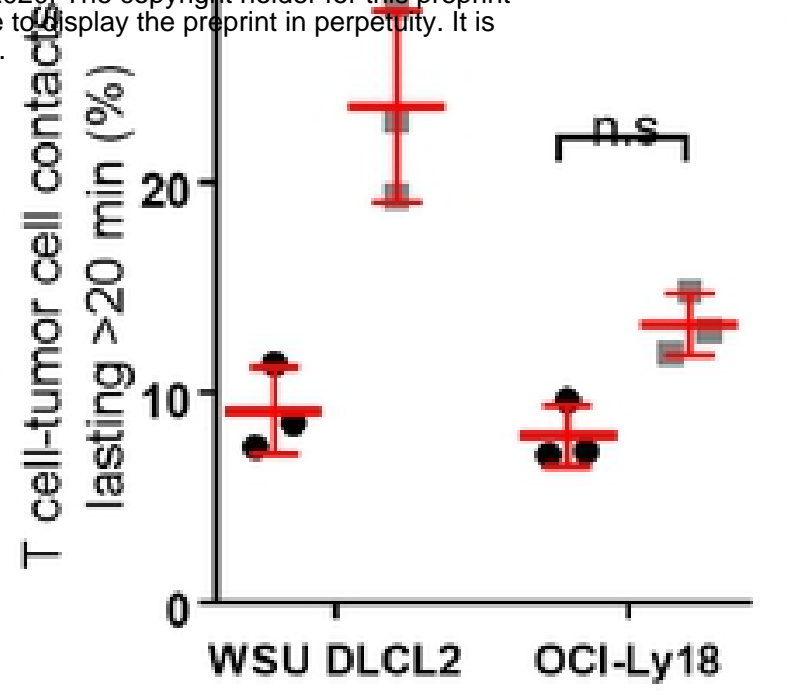

j

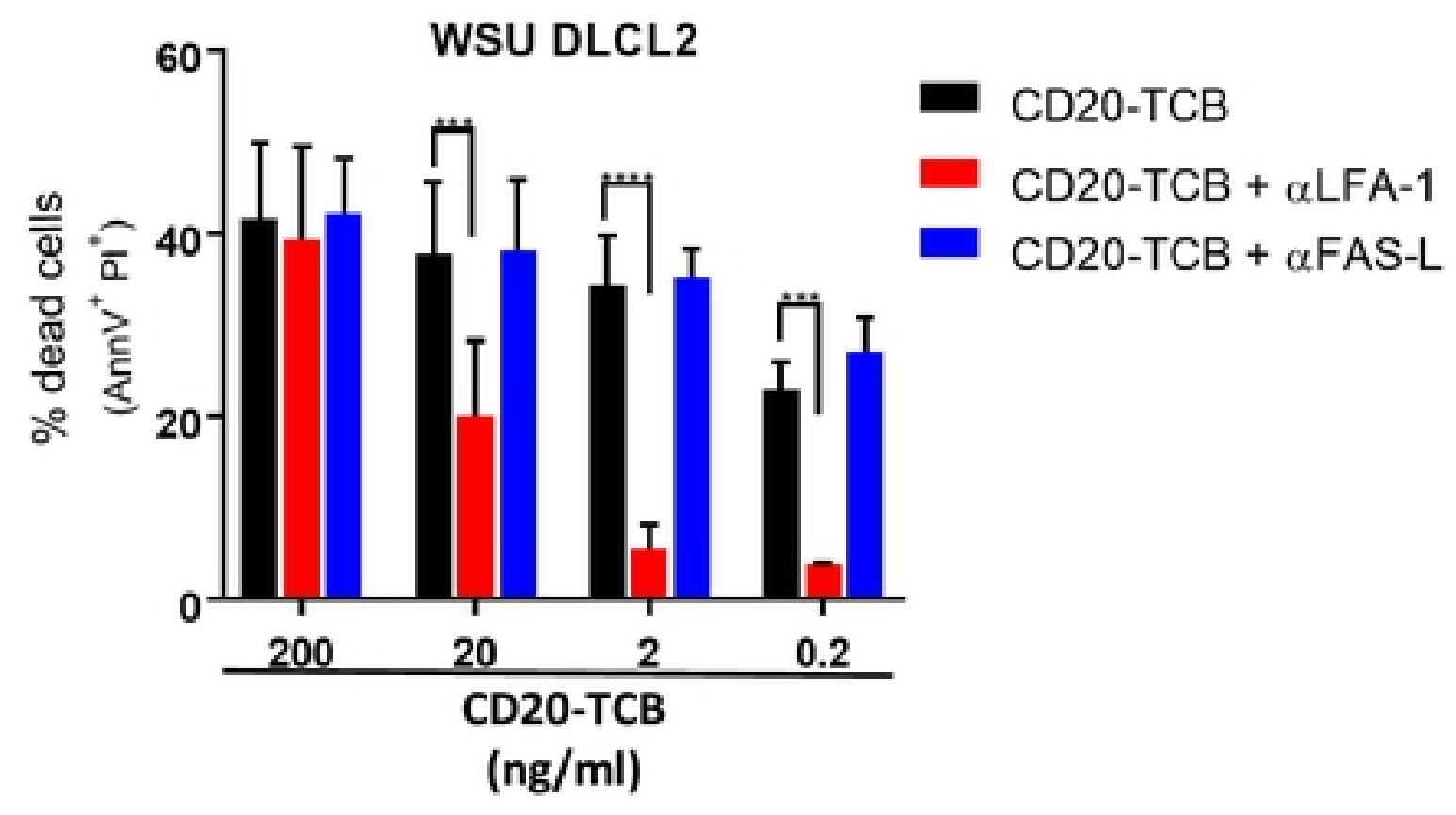


Figure 1: CD20-TCB mediates efficient tumor cell killing through stable synapses formation

a) Viability assay by AnnexinV $\left(\mathrm{AnnV}^{+}\right)$and Propidium lodide $\left(\mathrm{PI}^{+}\right)$staining on WSU DLCL2 and OCl-Ly18 cells, 16 hours after co-culture with $\mathrm{CD} 3 / \mathrm{CD} 28$ activated $\mathrm{CD}^{+} \mathrm{T}$ cells in the presence of the indicated CD20-TCB concentrations. $\mathrm{n}=4$ per point. Mean and $+/$ - s.d. are shown. 2 way-Anova, ${ }^{*} \mathrm{p}=0.05,{ }^{*} \mathrm{p}=0.005$, ${ }^{* * *} \mathrm{p}<0.0005$. b) $3 \mathrm{D}$ reconstruction of representative confocal imaging of synapse formation between $\mathrm{CD}^{+} \mathrm{T}$ cell (green) and tumor cell (blue), mediated by CD20-TCB treatment (red). c) 3D reconstruction of representative confocal imaging of Granzyme B (red) polarization toward the synapse between $\mathrm{CD}^{+} \mathrm{T}$ cell (green) and tumor cells (blue), mediated by CD20-TCB treatment (white). d-e) Confocal live cell imaging quantification of (d) Percentage of T cell-tumor cell contacts lasting more than 20 minutes; (e) $\mathrm{CD} 8^{+} \mathrm{T}$ cells speed $(\mu \mathrm{m} / \mathrm{min})$. Cells have been treated with $+/-$ CD20-TCB $(200 \mathrm{ng} / \mathrm{ml})$, in the presence of WSU DLCL2 or OCl-Ly18 cells as target. Mean and $+/$ - s.d. are shown, $\mathrm{n}=3$. 2 way-Anova, $* * \mathrm{p}<0.005 ;{ }^{* * * *} \mathrm{p}<0.0001$; n.s.: not significant. $\mathbf{f}-\mathbf{h})$ Confocal live cell imaging quantification of (f) Percentage of T cell-WSU DLCL2 contacts lasting more than 20 minutes; (g) contact area between T cells and WSU DLCL2, normalized by the total surface of tumor cells and (h) $C D 8^{+} T$ cells speed $(\mu \mathrm{m} / \mathrm{min})$. Cells have been treated with CD20TCB at the indicated doses. Mean and $+/-$ s.d. are shown, $n=3$. 2way-Anova, ${ }^{*} p<0.05 ; * * p<0.005$;

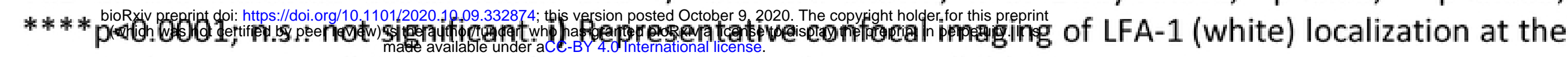
synapse between $T$ cell ( $\mathrm{F}$-actin is shown in green) and target cell (blue)

j) Viability assay by $\mathrm{AnnV}^{+}$and $\mathrm{PI}^{+}$staining of WSU DLCL2 cells, 16 hours after co-culture with $\mathrm{CD} 3 / \mathrm{CD} 28$ activated $\mathrm{CD} 8^{+} \mathrm{T}$ cells in the presence of the indicated CD20-TCB concentrations and +/- LFA-1 inhibitor $(10 \mu \mathrm{g} / \mathrm{ml})$ or $+/-$ FAS-L inhibitor $(10 \mu \mathrm{g} / \mathrm{ml}) . \mathrm{n}=4$ per point. Mean and $+/-\mathrm{s}$.d. are shown. 2 way-Anova, ${ }^{* * *}$ $\mathrm{p}<0.0005, * * * * \mathrm{p}<0.0001$. 
a

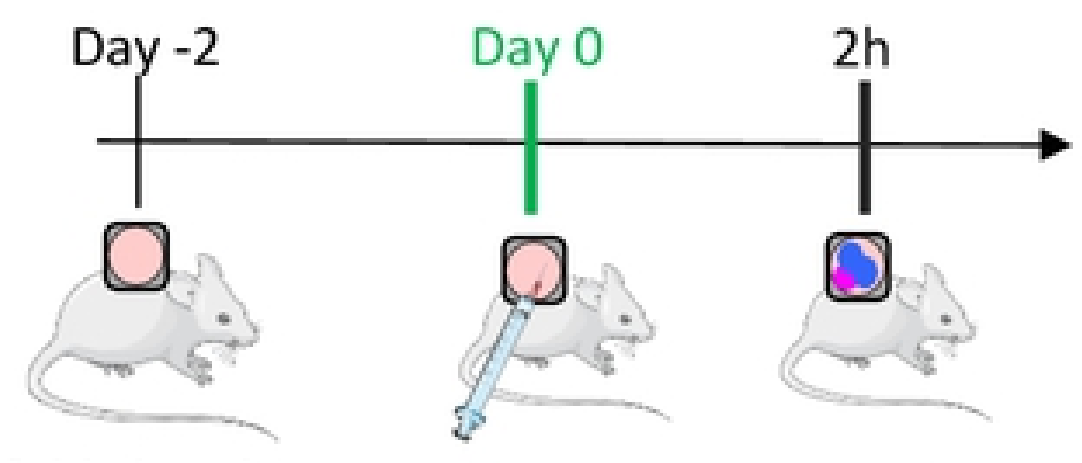

Skinfold chamber WSU DLCL2 Multiphoton surgery

\section{CT26 imaging}

+ - CD20TCB $(0.5 \mathrm{mg} / \mathrm{kg})$

b

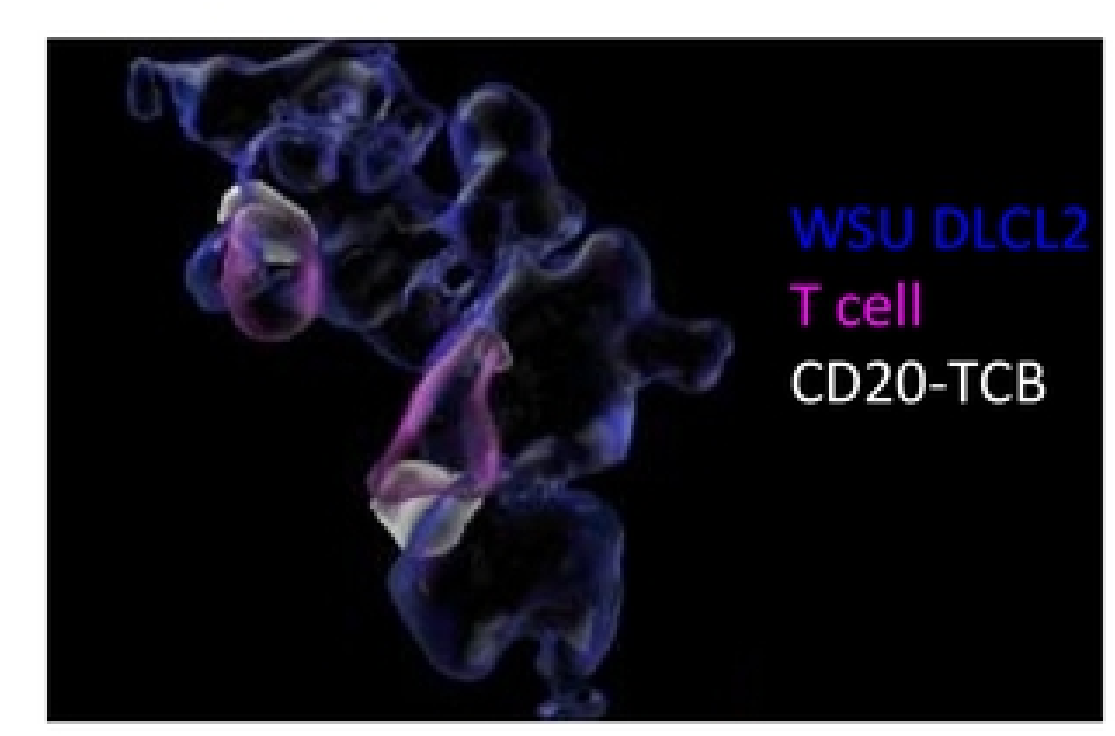

C

\section{CD20-TCB}

d

Speed $(\mu \mathrm{m} / \mathrm{min})$

\section{Vehicle}

October 9,2020 . The copyright holder for this prep 15 bioRxiv preprint doi: $h$ ttps://doi.org/10.1101/2020.10.09.332874; this version posted October 9 , 2020. The copyright holder for this prep
(which was not certified by peer review) is the

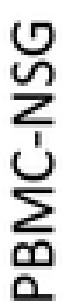

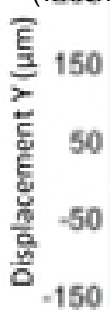
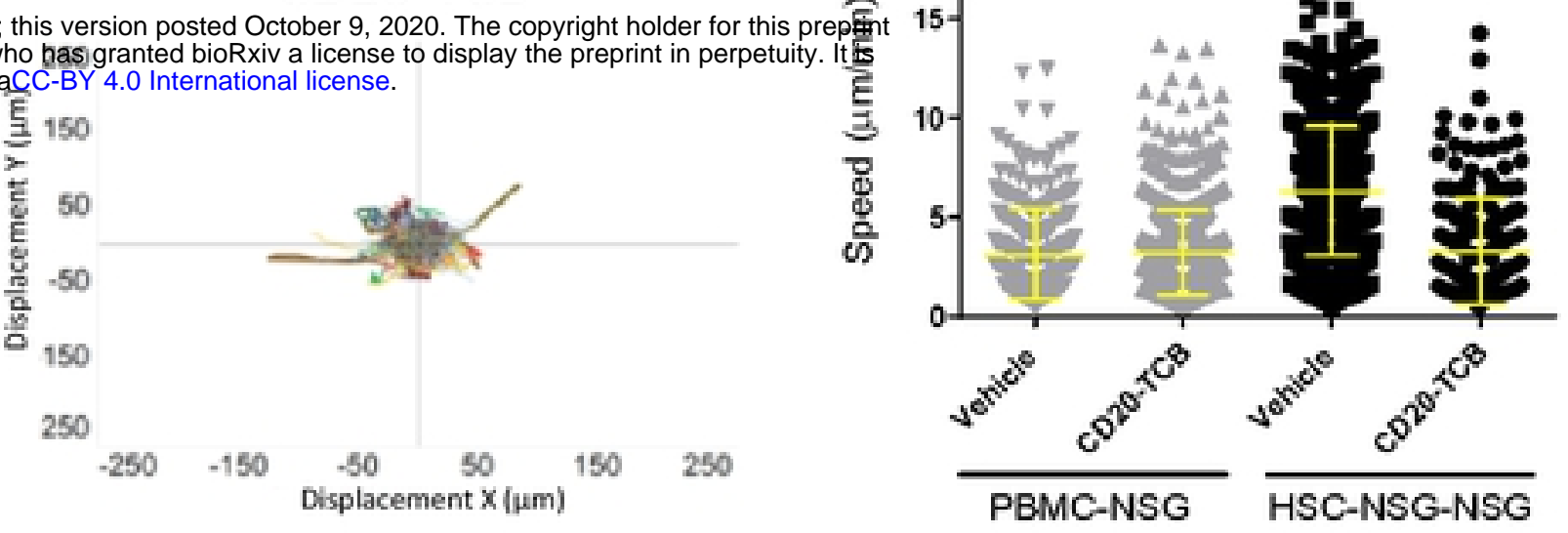

U
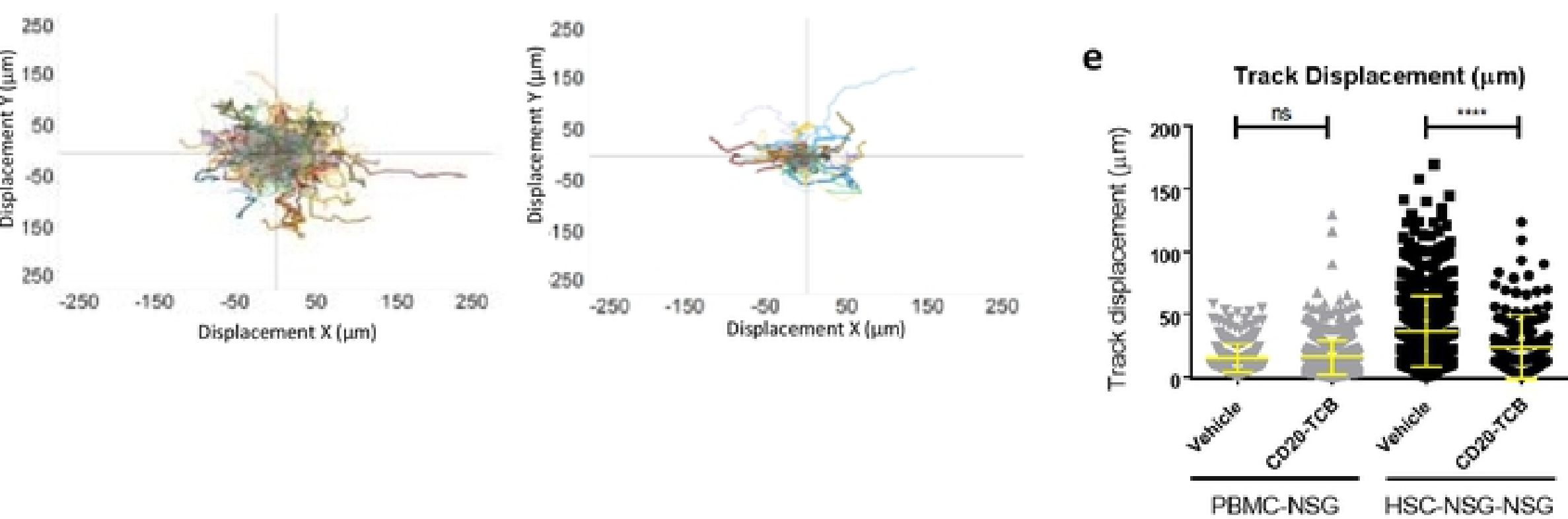


\section{Figure 2: A xenoreaction-free model to quantify $\mathrm{T}$ cell dynamics in response to therapy}

a) Workflow schematics: skinfold chambers were installed on NSG mice (day -2). 48 hours later (day 0): WSU DLCL2 (blue), unstained CT26 cells, and $C D 2^{+} T$ cells (pink) freshly purified from human PBMCs or from HSC-NSG mice were injected intra-dermally in the skinfold chamber together with labeled CD20-TCB $(0.5 \mathrm{mg} / \mathrm{kg})$ or with suitable vehicle. Cells were imaged 2 hours post treatment by MP-IVM. Adapted from https://smart.servier.com/. b) 3D representative rendering of MP-IVM imaging on skinfold chamber of HSC-NSG-NSG mice showing localization of therapy (white) at the contact site between WSU DLCL2 cells (blue) and T cells (pink), 2 hours post treatment. c) MP-IVM analysis of T cells tracks in the skin fold chamber of PBMC-NSG (top) vs HSC-NSG-NSG mice (bottom), +/- CD20-TCB. T cell tracks are plotted according to their displacement in the $X$ and $Y$ axes. Total number of tracks for each plot is: Top left: Vehicle $n=330$. Top right: CD20-TCB $n=759$. Bottom left: Vehicle $n=741$. Bottom right: CD20-TCB $n=185$. $d-$

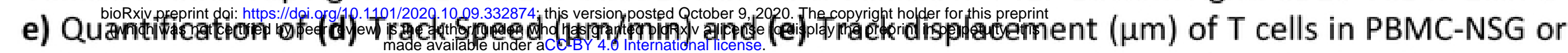
HSC-NSG-NSG mice, +/- CD20-TCB. Shown in yellow are mean values +/- s.d. Unpaired t-test; $* * * * p<0.0001 ;$ n.s.: not significant. 
Figure 3: CD20-TCB induces early and lasting T cell engagement and activity

a) Time course quantification of Speed $(\mu \mathrm{m} / \mathrm{min})$, Track displacement $(\mu \mathrm{m})$ and Arrest coefficient $(\%)$ of HSC-NSG-derived T cells co-injected with WSU DLCL2 tumor cells in NSG mice, treated with $0.5 \mathrm{mg} / \mathrm{kg}$ CD20-TCB i.v. or suitable vehicle and imaged starting from 30 minutes after treatment for 2 hours. Statistics: Kruskal-Wallis test, $* * * *$ Adj. P value $<0.0001$. Shown are mean values +/- SEM b) Time course tracking of T cells after intravenous injection of $0.5 \mathrm{mg} / \mathrm{kg}$ CD20-TCB. Highlighted are the 3 different possible behaviors of T cells: i) This T cell is moving fast at the beginning, with a straight trajectory. When it encounters a tumor cell in the presence of therapy, it suddenly stops, and starts interacting (light blue arrow). ii) This cell is interacting with the tumor since the beginning, its track is revolving around the same coordinates (yellow arrow). iii) This cell does not interact with the environment (light blue arrow). WSU DLCL2 cells are represented in blue, T cell in pink. Tracks are shown for each T cell in the field. c) Shown are $T$ cell tracks, plotted according to their displacement in the $X$ and $Y$ axes. Comparison of tracks of $T$ cells treated intravenously with $0.5 \mathrm{mg} / \mathrm{kg} \mathrm{CD20}-\mathrm{TCB}$ or with suitable vehicle. Each animal has been imaged over time for $1 \mathrm{~h}$ at 24,48 or $72 \mathrm{~h}$ after treatment. $24 \mathrm{~h}$ : Vehicle $n=403, C D 20-T C B n=348$. $48 \mathrm{~h}$ : Vehicle $n=195$, CD20-TCB n=49. 72h: Vehicle $n=353$, CD20TCB n=127. d-g) Quantification of (d) Speed

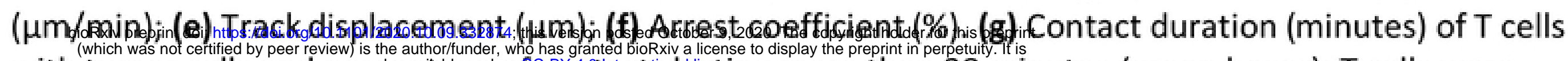

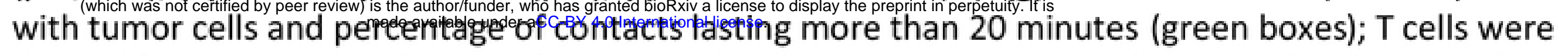
derived from HSC-NSG spleens and co-injected with WSU DLCL2 tumor cells, treated with $0.5 \mathrm{mg} / \mathrm{kg} \mathrm{CD20}$ -TCB i.v. or suitable vehicle and imaged 24,48 or 72 hours post treatment. Statistics: Kruskal-Wallis test, **** Adj. P value $<0.0001, * *$ Adj. P value $<0.005$. Shown are scattered plots and means +/- s.d. 
Fig.4
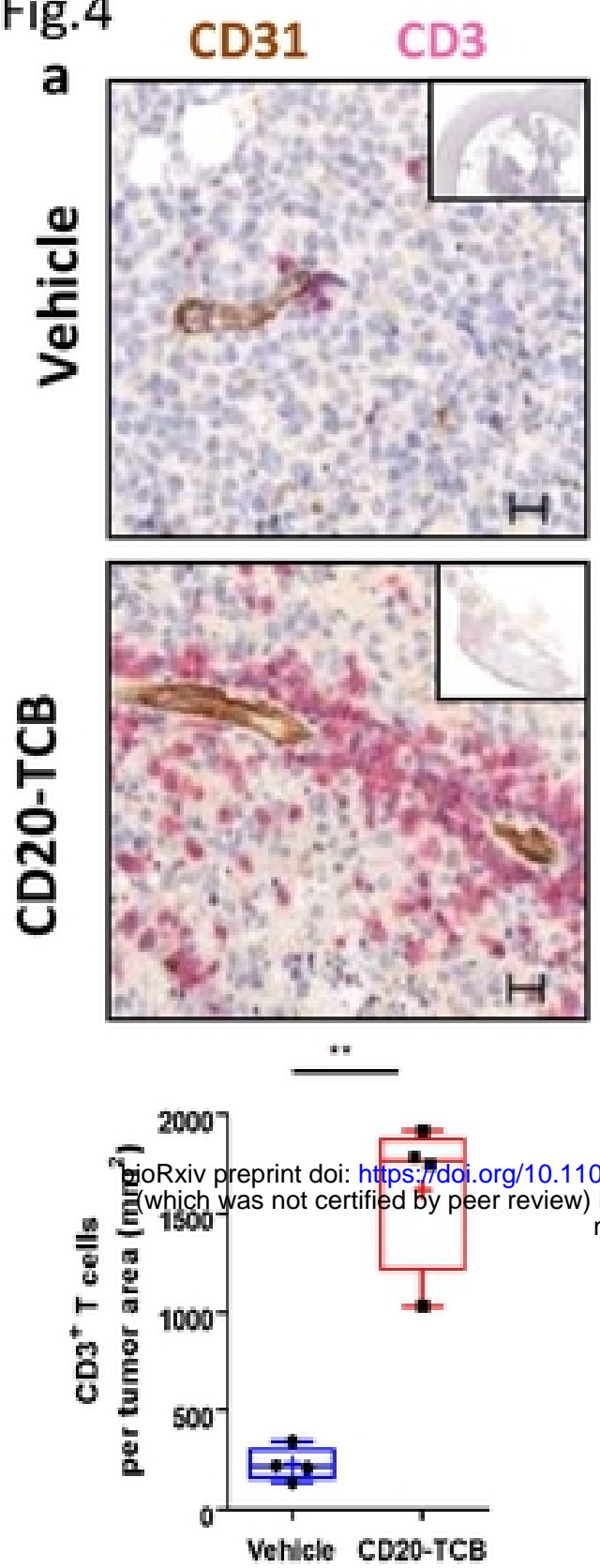

d

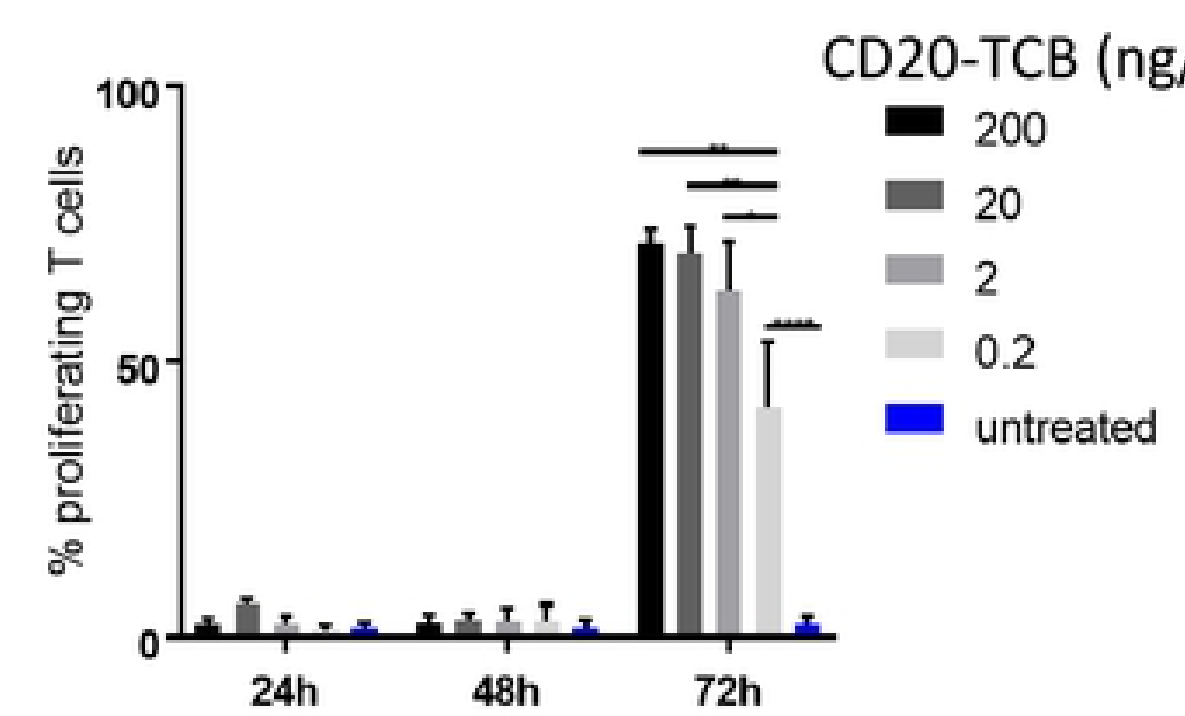

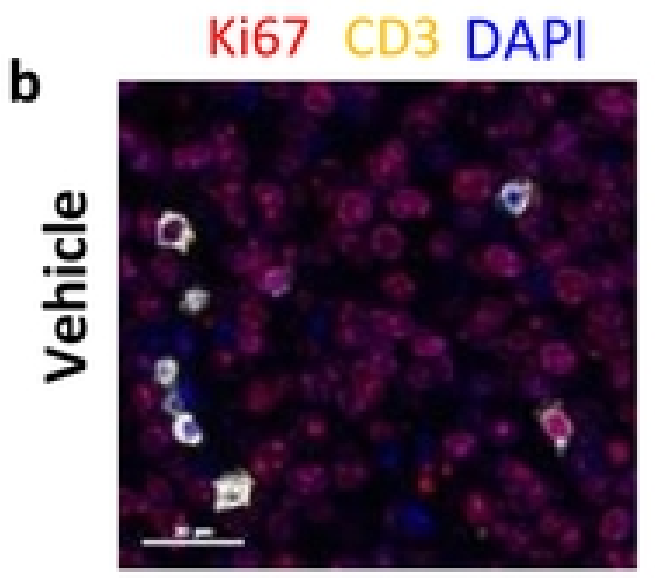
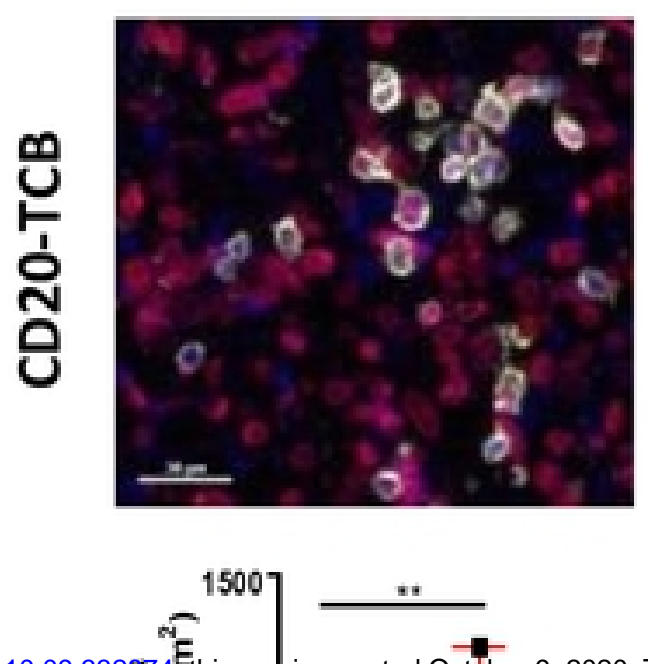
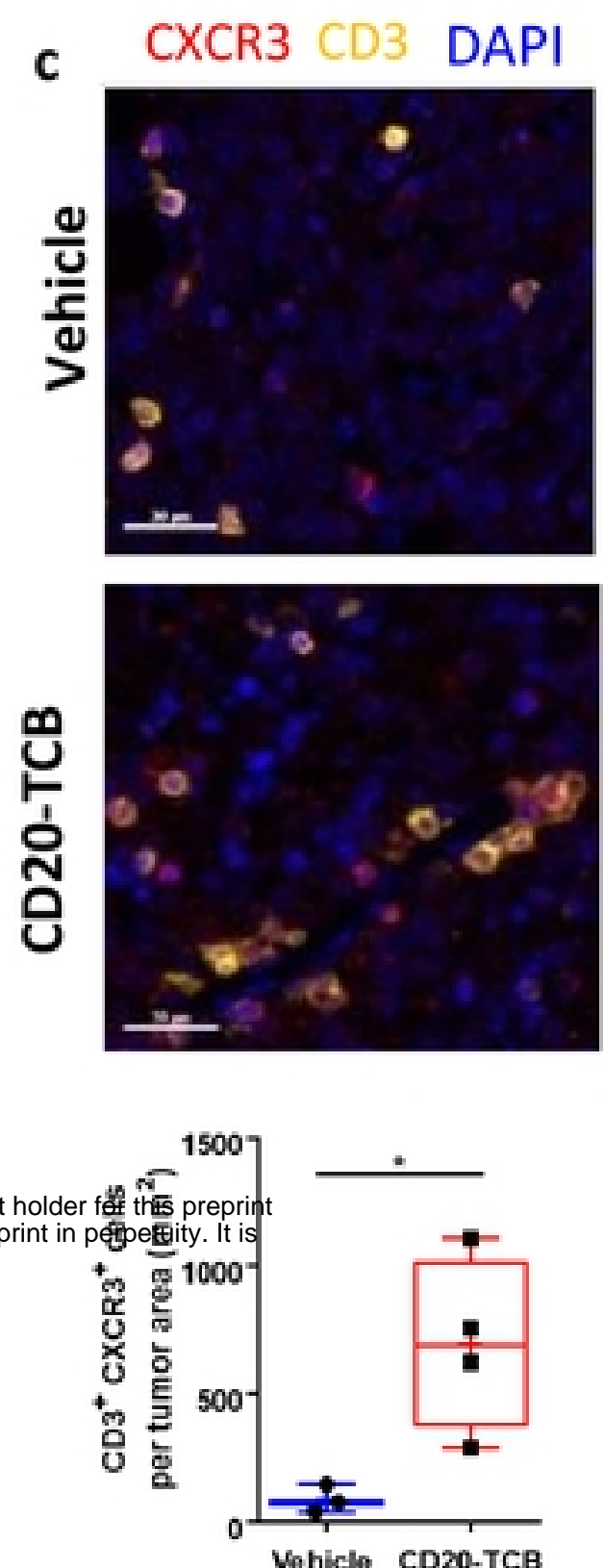

e

Day 0

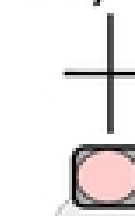

Skinfold

chamber

surgery

WSU DLCL2 CT26

Resident T cells

Therapy

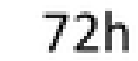

$72 \mathrm{~h}$

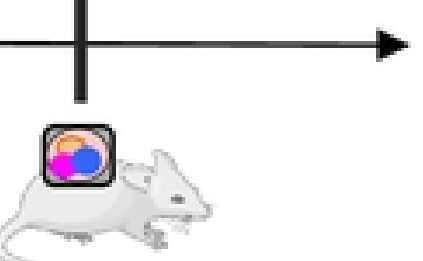

Multiphoton

imaging g

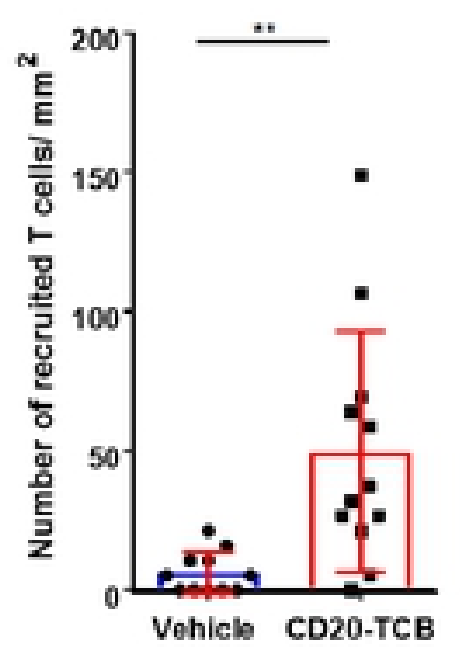

Vehicle CD20-TCB

Resident T cells

Recruited T cells

WSU DLCL2

ho
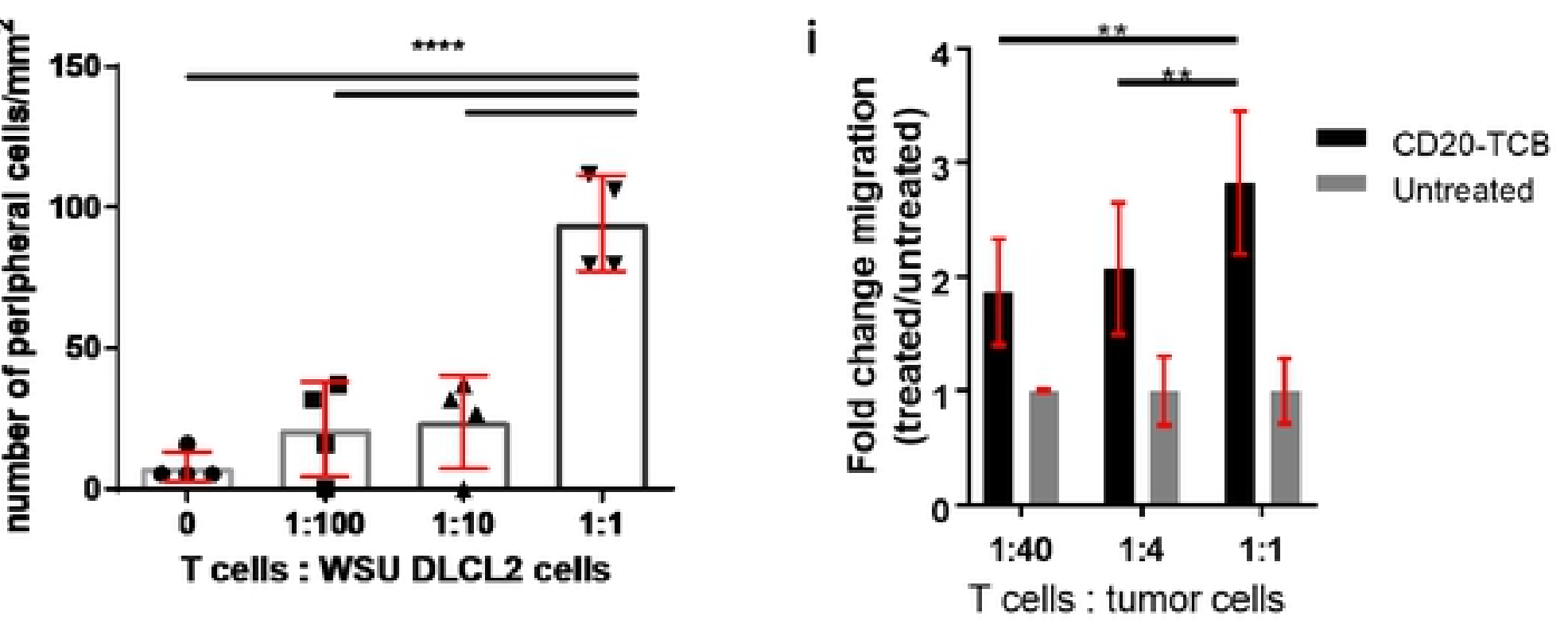
Figure 4: CD20-TCB induces resident T cell proliferation and recruitment of peripheral blood T cells

a-c) Top: Representative histological staining of WSU DLCL2 tumors $24 \mathrm{~h}$ post second treatment $(0.5 \mathrm{mg} / \mathrm{kg}$ CD20-TCB or suitable vehicle i.v.). Bottom: Quantification of total number of cells $/ \mathrm{mm}^{2}$ from histological images of vehicle vs CD20-TCB treatment. Whole slide scans quantification of $4 \mu \mathrm{m}$ FFPE sections with the software (a) Definiens; (b-c) Halo. Statistical analysis: Unpaired 2-tailed t-test with Welch's correction. ${ }^{*} p<0.05,{ }^{* *} p<0.005$ (a) Red: CD3 staining, brown: CD31 staining. Quantification: number of CD3 ${ }^{+}$cells b) red: Ki67, yellow: CD3, blue: DAPI. Quantification: number of $\mathrm{CD}^{+} \mathrm{Ki}^{+} 7^{+}$cells c) Red: $\mathrm{CXCR3}$, yellow: CD3, Blue: DAPI. Quantification of $\mathrm{CD}^{+}{ }^{+} \mathrm{CXCR}^{+} \mathrm{T}$ cells. d) Percentage of proliferating $\mathrm{CD} 8^{+} \mathrm{T}$ cells, as assessed by CFSE dilution, freshly purified from PBMCs. Proliferation has been evaluated at $24 \mathrm{~h}, 48 \mathrm{~h}$ and $72 \mathrm{~h}$ post CD20-TCB treatment, at the indicated doses, in the presence of WSU DLCL2 cells as target. $n=3$ per group, mean and s.d. are shown. One-way Anova, ${ }^{*} \mathrm{p}<0.05,{ }^{* *} \mathrm{p}<0.005,{ }^{* * * *} \mathrm{p}<0.0001$

e) Workflow schematics: Skinfold chamber were installed on NSG mice. 48h later, WSU DLCL2 (Blue), unstained $\mathrm{CT} 26$ cells, and $\mathrm{CD}^{+}{ }^{+} \mathrm{T}$ cells freshly purified from HSC-NSG spleens (pink) were injected intradermally in the skinfold chamber, together with $0.25 \mathrm{mg} / \mathrm{kg}$ of CD20-TCB or with suitable vehicle. Concomitantly, freshly purified $\mathrm{CD}^{+} \mathrm{T}$ cells from HSC-NSG spleens (orange) were injected i.v. to allow

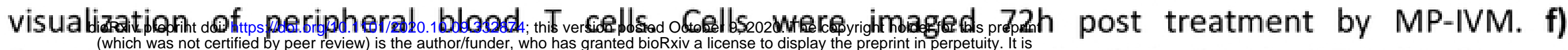

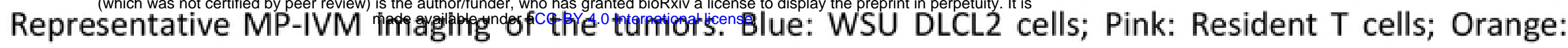
Recruited T cells. Images were acquired $72 \mathrm{~h}$ post intradermal treatment with $0.25 \mathrm{mg} / \mathrm{kg}$ CD20-TCB or suitable vehicle. Adapted from https://smart.servier.com/ g) Quantification of peripheral $\mathrm{T}$ cells (number $/ \mathrm{mm}^{2}$ ) $72 \mathrm{~h}$ post treatment. Mean +/- s.d. are shown. Unpaired 2-tailed t-test with Welch's correction. ${ }^{* *} \mathrm{p}<0.005$. h) In the context of the skinfold chamber model, increasing number of $\mathrm{T}$ cells (Resident) were co-injected with the tumor and $0.25 \mathrm{mg} / \mathrm{kg}$ of CD20-TCB intradermally, while $2.5^{*} 10^{6} \mathrm{~T}$ cells were injected intravenously (Peripheral). $72 \mathrm{~h}$ post treatment, peripheral blood $\mathrm{T}$ cells were counted for each tumor from 5 representative fields. 4 tumors per group were analyzed. Shown is the count of peripheral T cells $/ \mathrm{mm}^{2}$, Mean + /- s.d. per group. Statistical analysis: One-way Anova. $* * * * p<0.0001$. i) 3 hours in vitro chemotaxis assay of T cells toward preconditioned medium derived from WSU DLCL2 COculture with $\mathrm{CD} 3 / \mathrm{CD} 28$ pre-activated T cells. Pre-activated CD8 T cells have been plated with WSU DLCL2 cells at decreasing T cells : tumor cells ratios, in the presence of $200 \mathrm{ng} / \mathrm{ml}$ of CD20-TCB. $24 \mathrm{~h}$ later the supernatant has been collected and transferred to the bottom chamber of a 24-Transwell plate. In the top chamber 100.000 pre activated T cells, labeled with CFSE, have been seeded and let to migrate for 3 hours. Migration has been evaluated by counting total amount of CFSE positive migrated cells in the bottom chamber, by flow cytometry at constant volume and acquisition speed. Mean fold change and $+/-$ s.d. are shown. $n=5$, from two independent experiments 2-way Anova; ** $p<0.005$ 


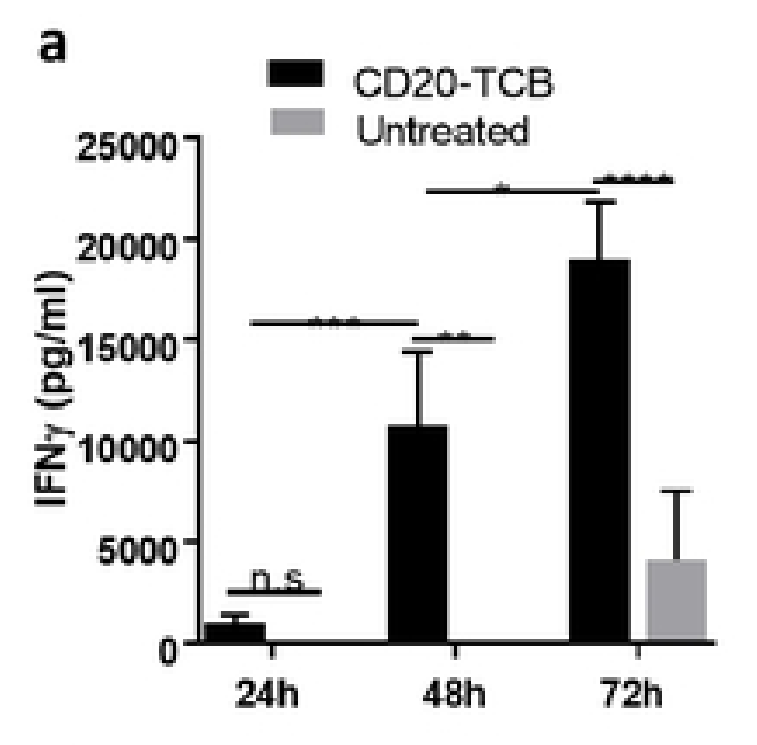

d

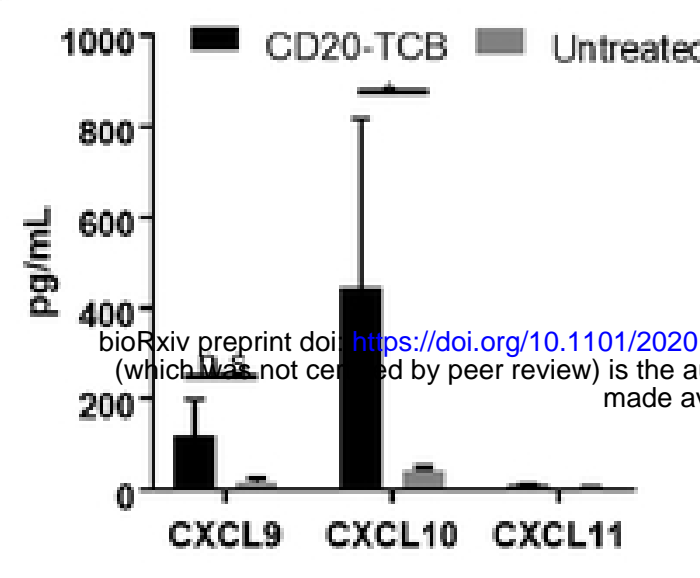

b

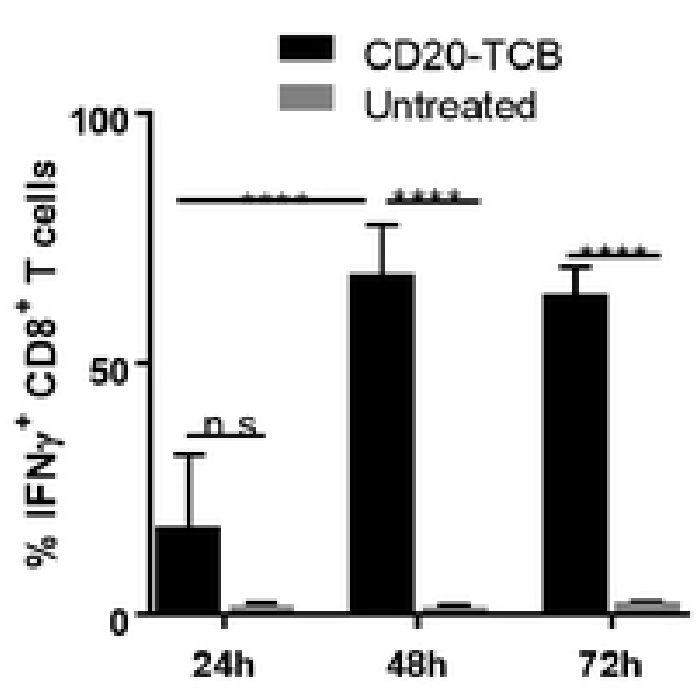

e

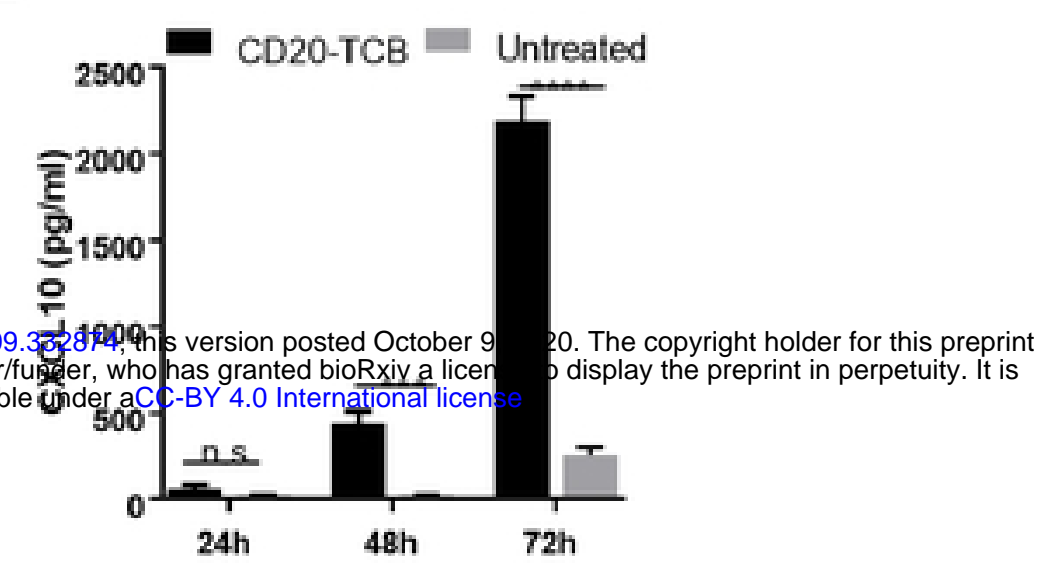

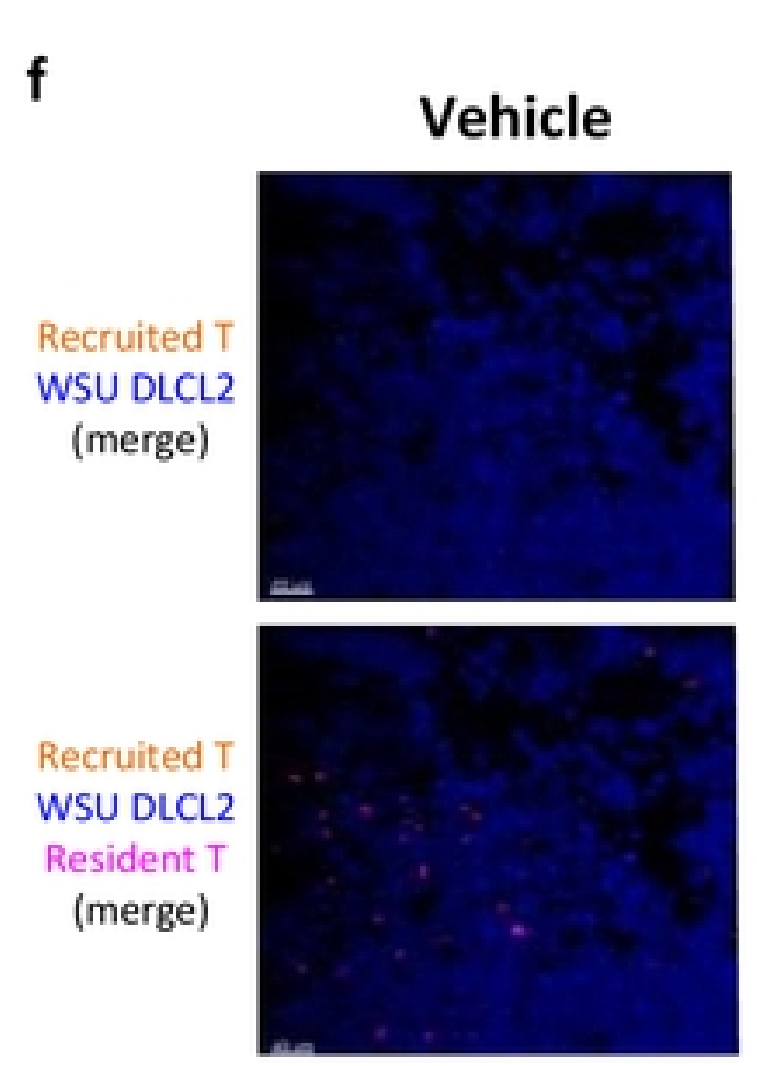

IFNy tumor pretreatment
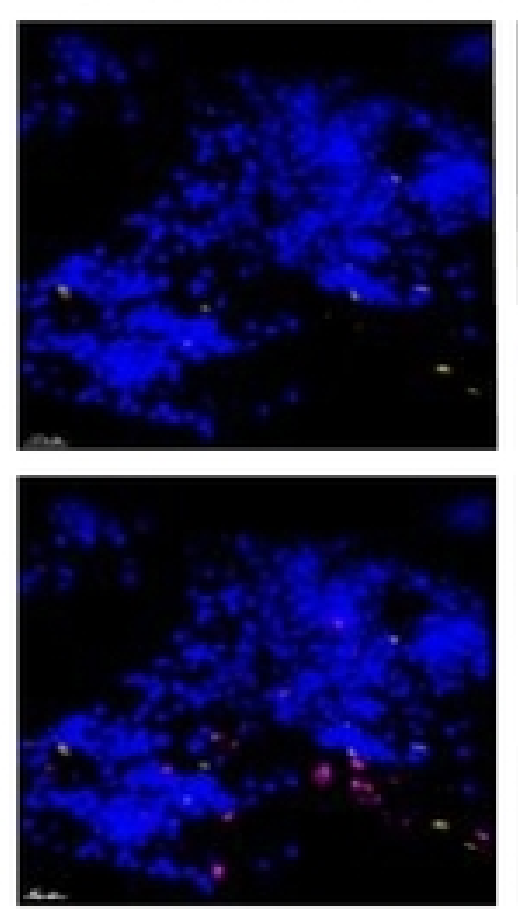

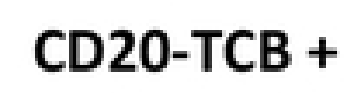
aCXCL10
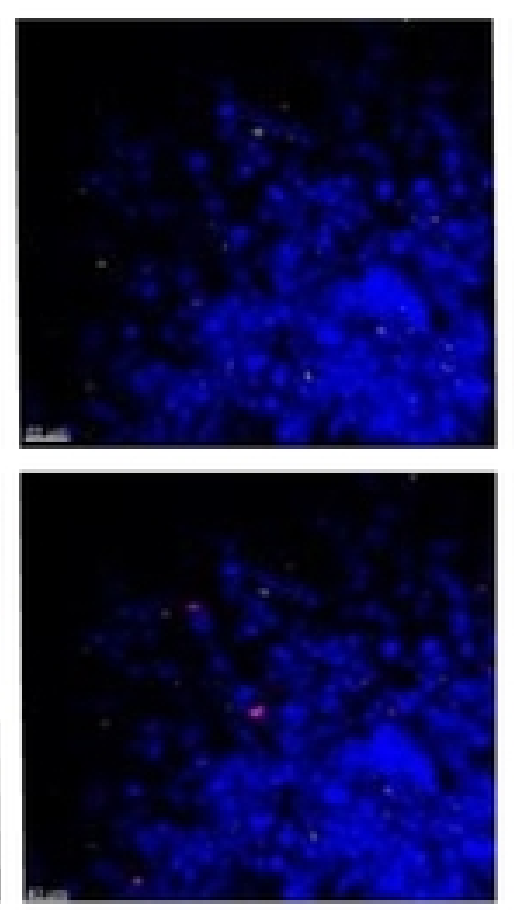

CD20-TCB + $\alpha$ IFN $\gamma$
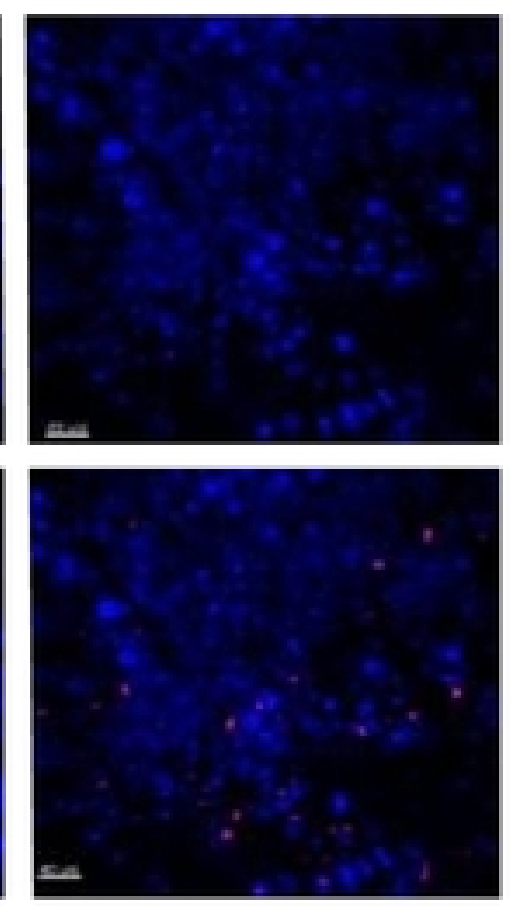

g
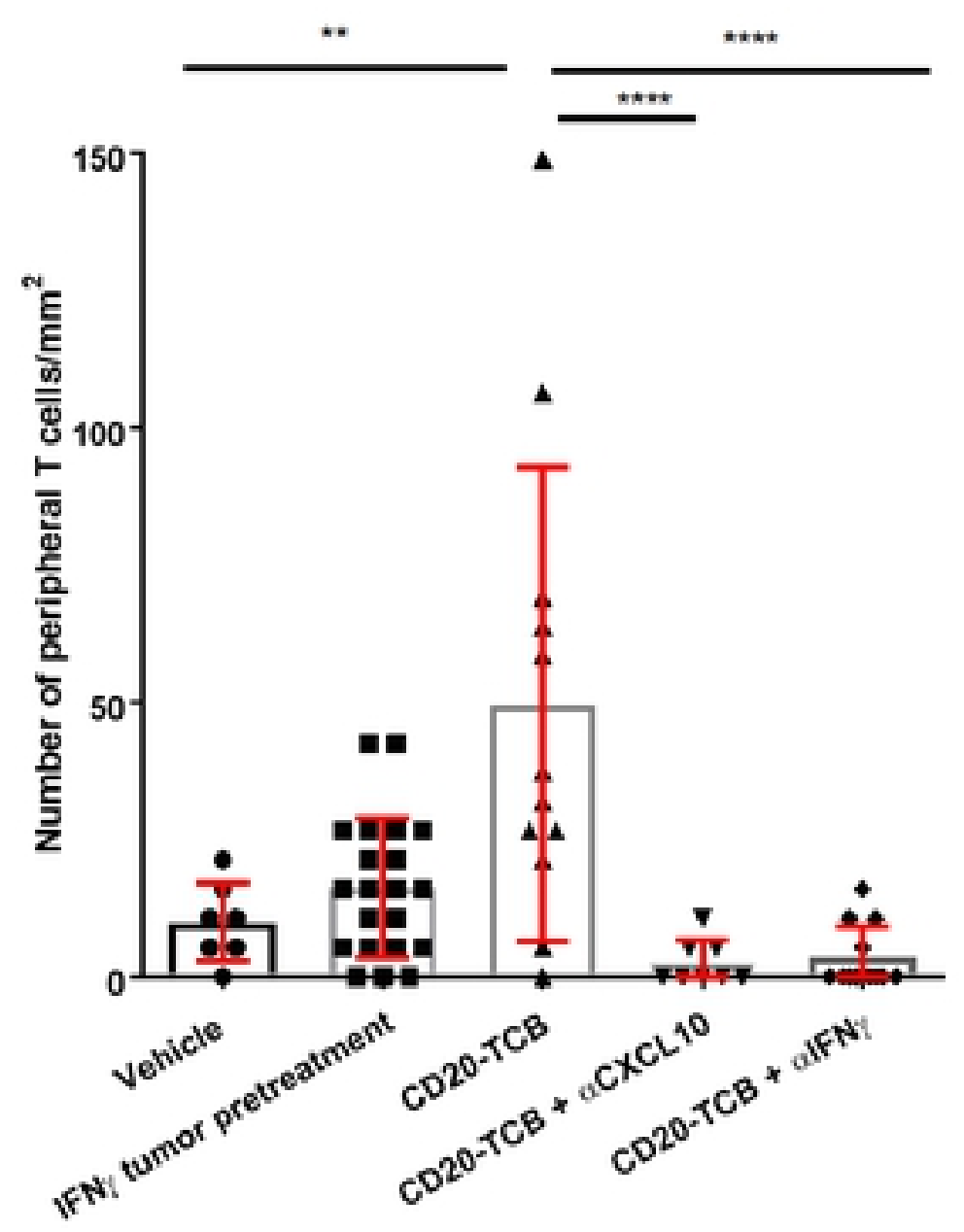
Fig.5: CD20-TCB-induced T cell recruitment is dependent on IFN $\gamma$ and CXCL10

a) IFN $\gamma$ protein quantification by multiplex analysis of supernatant derived from co-culture of WSU DLCL2 cells with CD8 ${ }^{+} T$ cells freshly purified from PBMCs and stimulated with CD20-TCB $(200 \mathrm{ng} / \mathrm{ml})$ at the indicated time points. $\mathrm{n}=3$ per group. Two-way Anova. ${ }^{*} \mathrm{p}<0.05,{ }^{* *} \mathrm{p}<0.05,{ }^{* * *} \mathrm{p}<0.001,{ }^{* * * *} \mathrm{p}<$ 0.0001 , n.s.: not significant. b) Flow cytometry analysis of CD8 $8^{+} I N F \gamma^{+} T$ cells, at 24,48 and 72 hours post in vitro CD20-TCB $(200 \mathrm{ng} / \mathrm{ml})$ treatment. c) Quantification of released cytokines $(\mathrm{pg} / \mathrm{mL})$ upon IFNy stimulation of WSU DLCL2 tumor cells for 48 hours. Shown is Mean +/- s.d. of 3 replicates. d) Quantification of released cytokines $(\mathrm{pg} / \mathrm{mL})$ upon CD20-TCB treatment $(200 \mathrm{ng} / \mathrm{ml})$ of WSU DLCL2 cocultured with $\mathrm{CD} 3 / \mathrm{CD} 28$ pre-activated $\mathrm{CD}^{+} \mathrm{T}$ cells. Shown is Mean $+/-$ s.d. $n=4$ per group. Two-way Anova $* p<0.05$, n.s.: not significant. e) CXCL10 protein quantification by multiplex analysis of supernant derived from co-culture of WSU DLCL2 cells with $C D 8^{+} T$ cells freshly purified from PBMCs and stimulated with CD20-TCB $(200 \mathrm{ng} / \mathrm{ml})$ at the indicated time points. $\mathrm{n}=3$ per group. Two-way Anova. ${ }^{* * *} \mathrm{p}<0.001$, $* * * * p<0.0001$, n.s. not significant. f) Representative images from MP-IVM imaging in the skinfold chamber of HSC-NSG-NSG mice. WSU DLCL2 cells (blue) pre-treated or not with IFN $\gamma$ were injected intradermally together with $\mathrm{CD2}^{+} \mathrm{T}$ cells derived from the spleen of HSC-NSG (pink) and $0.25 \mathrm{mg} / \mathrm{kg} \mathrm{CD} 20-\mathrm{TCB}$

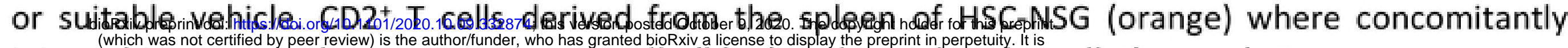
injected intravenously. Tops aro cells (blue), resident T cells (pink) and peripheral T cells (orange). Where indicated, antibodies against CXCL10 or IFNy were injected intravenously. g) Quantification of peripheral blood T cells (count $/ \mathrm{mm}^{2}$ ) 72 hours post treatment. Shown are individual counts $/ \mathrm{mm}^{2}$ and mean $+/-$ s.d. Statistical analysis: One-way Anova. ${ }^{* * *} \mathrm{p}<0.001,{ }^{* * * *} \mathrm{p}<0.0001$. 


\begin{tabular}{|c|c|c|c|c|c|c|c|c|c|c|c|c|}
\hline \multirow[b]{3}{*}{ Index } & \multicolumn{6}{|c|}{$<24$ hours (early) } & \multicolumn{6}{|c|}{$>24$ hours (late) } \\
\hline & \multicolumn{3}{|c|}{ vehicle } & \multicolumn{3}{|c|}{ CD20-TCB } & \multicolumn{3}{|c|}{ vehicle } & \multicolumn{3}{|c|}{ CD20-TCB } \\
\hline & Mean & S.E.M & $\mathrm{N}$ & Mean & S.E.M & $\mathrm{N}$ & Mean & S.E.M & $\mathrm{N}$ & Mean & S.E.M & $\mathrm{N}$ \\
\hline Meandering index & 0.3783 & 0.006055 & 3 & 0.3085 & 0.01007 & 2 & 0.3968 & 0.006823 & 6 & 0.3369 & 0.005316 & 7 \\
\hline Speed (um/min) & 5.588 & 0.07982 & 3 & 2.448 & 0.104 & 2 & 4.42 & 0.07334 & 6 & 2.256 & 0.04495 & 7 \\
\hline Track displacement ( $\mu \mathrm{m})$ & 32.28 & 0.6849 & 3 & 17.02 & 0.9613 & 2 & 23.3 & 0.5799 & 6 & 13.6 & 0.2876 & 7 \\
\hline Contact duration (min) & 3.444 & 0.05564 & 3 & 7.74 & 0.2048 & 2 & 3.918 & 0.0758 & 6 & 7.343 & 0.1378 & 7 \\
\hline Arrest coefficient (\$) & 36.87 & 0.8229 & 3 & 72.7 & 1.39 & 2 & 44.06 & 0.9013 & 6 & 78.22 & 0.5674 & 7 \\
\hline
\end{tabular}

Table 1: Reference average values of T cell dynamic indexes in tumors treated with $0.5 \mathrm{mg} / \mathrm{kg} \mathrm{CD20-TCB}$ intravenously or with suitable vehicle, at early (less than $24 \mathrm{~h}$ ) or late (more than $24 \mathrm{~h}$ ) time points.

- The meandering index indicates the kind of movement of T cells. A meandering index of 0.5 indicates random movement, 1 indicates directional movement, and a meandering index of 0 indicates a cell

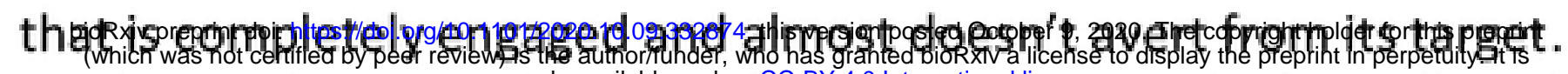

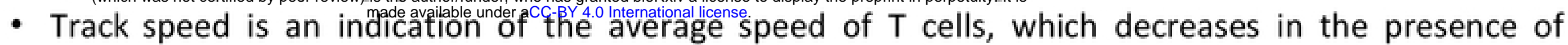
interaction and engagement.

- Track displacement is another indicator of the way T cells move: the higher the track displacement, the further the cells migrate during acquisition, showing less interaction with the surrounding tumor.

- Contact duration represents the average contact duration between T cell-tumor cells.

- The arrest coefficient indicates the percentage of cells that slow down to less than $2 \mu \mathrm{m} / \mathrm{min}$, with a higher arrest coefficient meaning more arrested (and thus engaged) cells. 
a

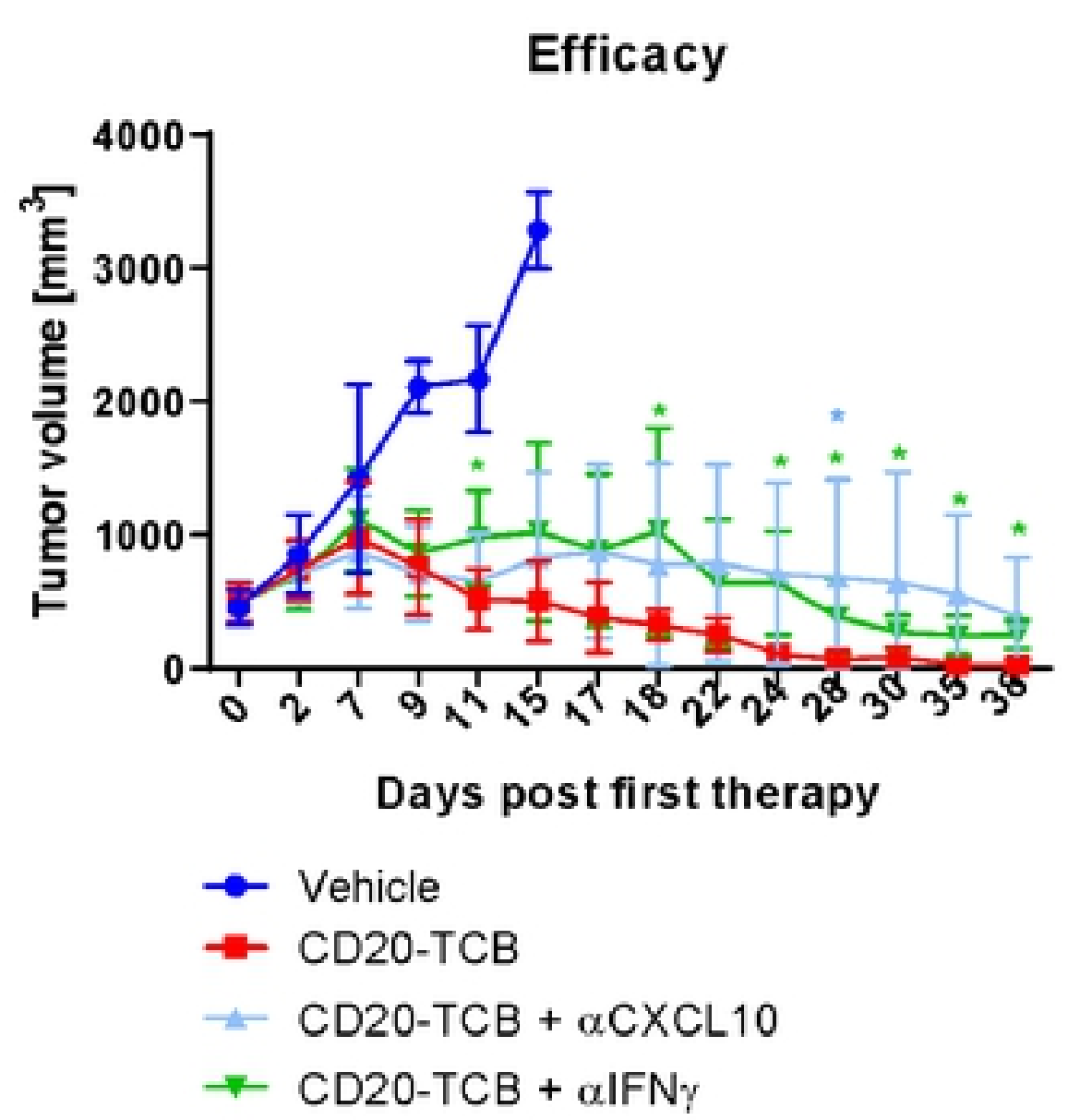

b
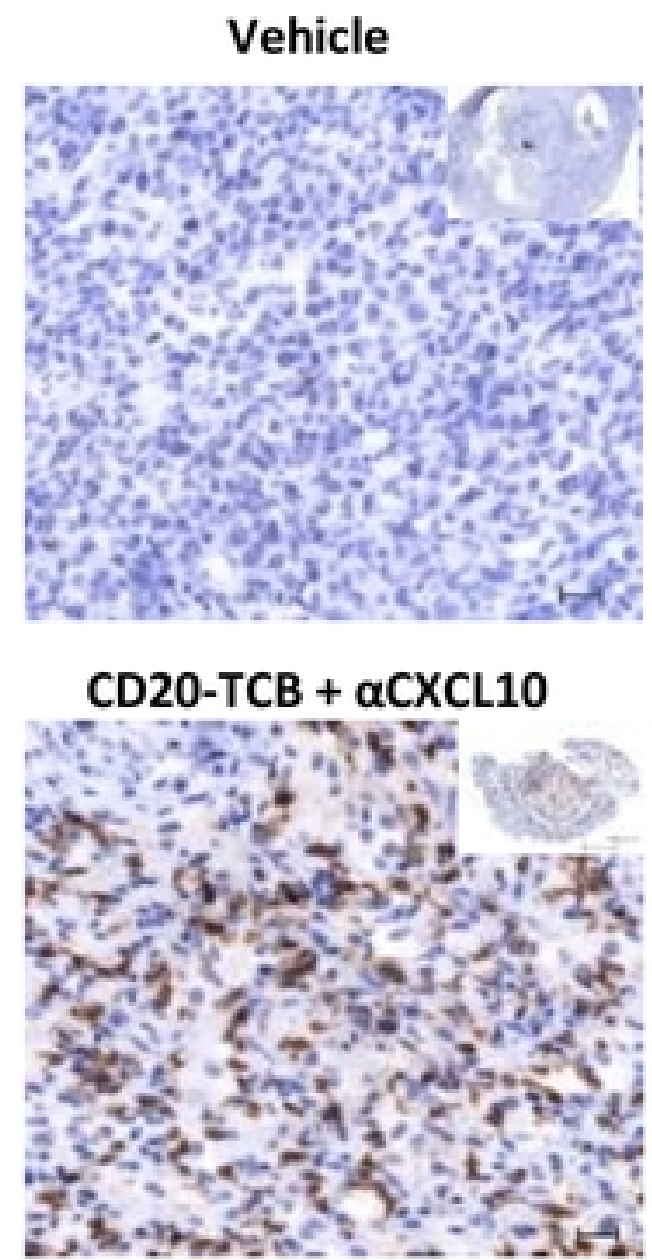
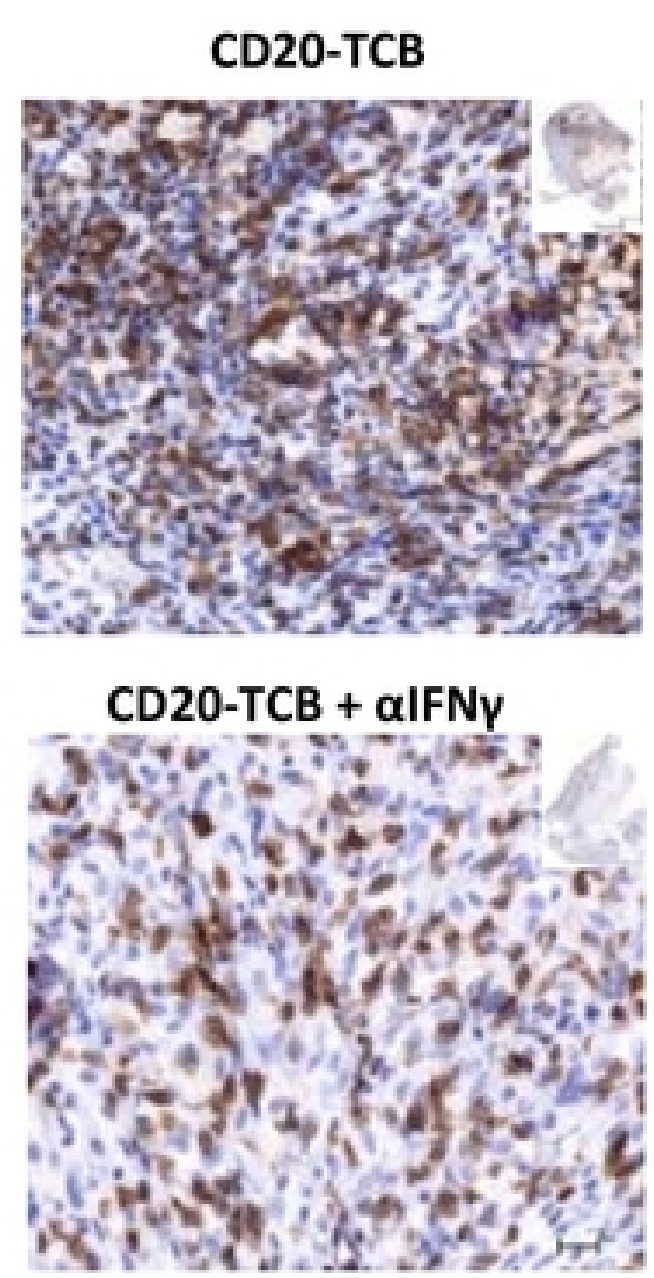

c

bioRxiv preprint doi: https://doi.org/10.1101/2020.10.09.332874; this version posted October 9, 2020. The copyright holder for this preprin

葛

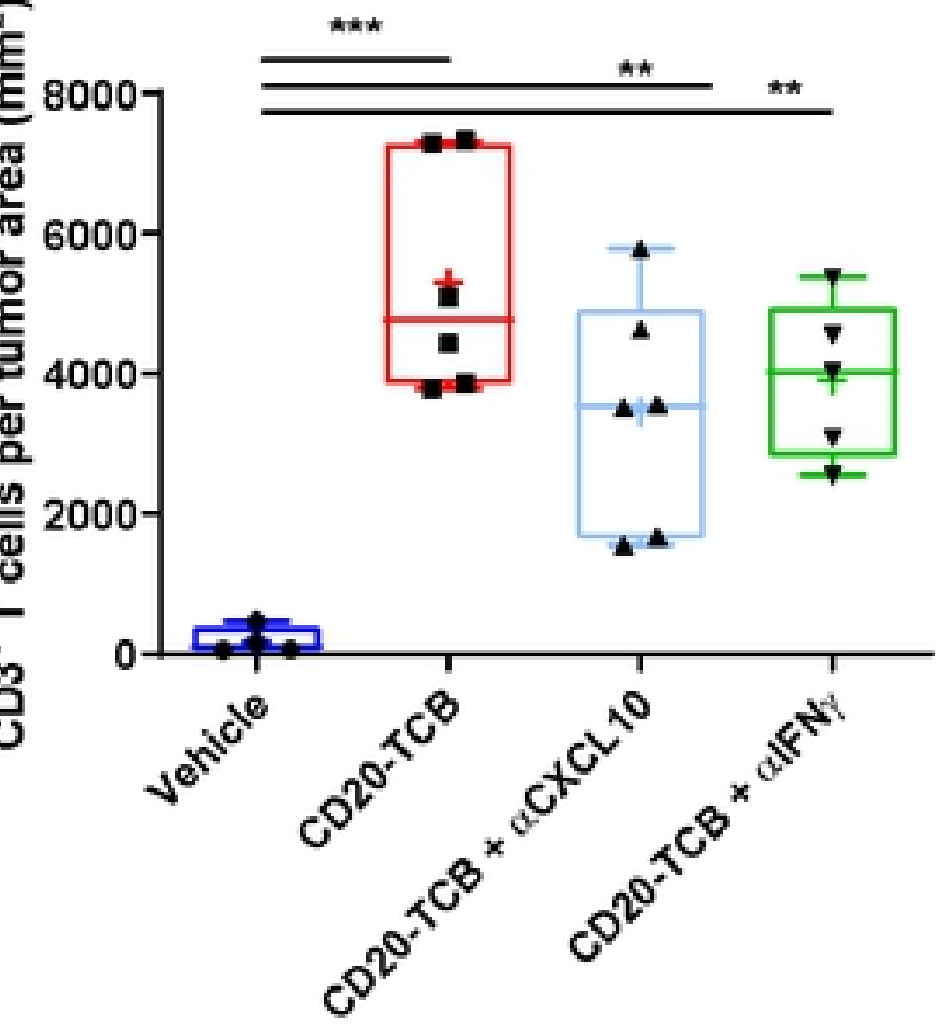

d

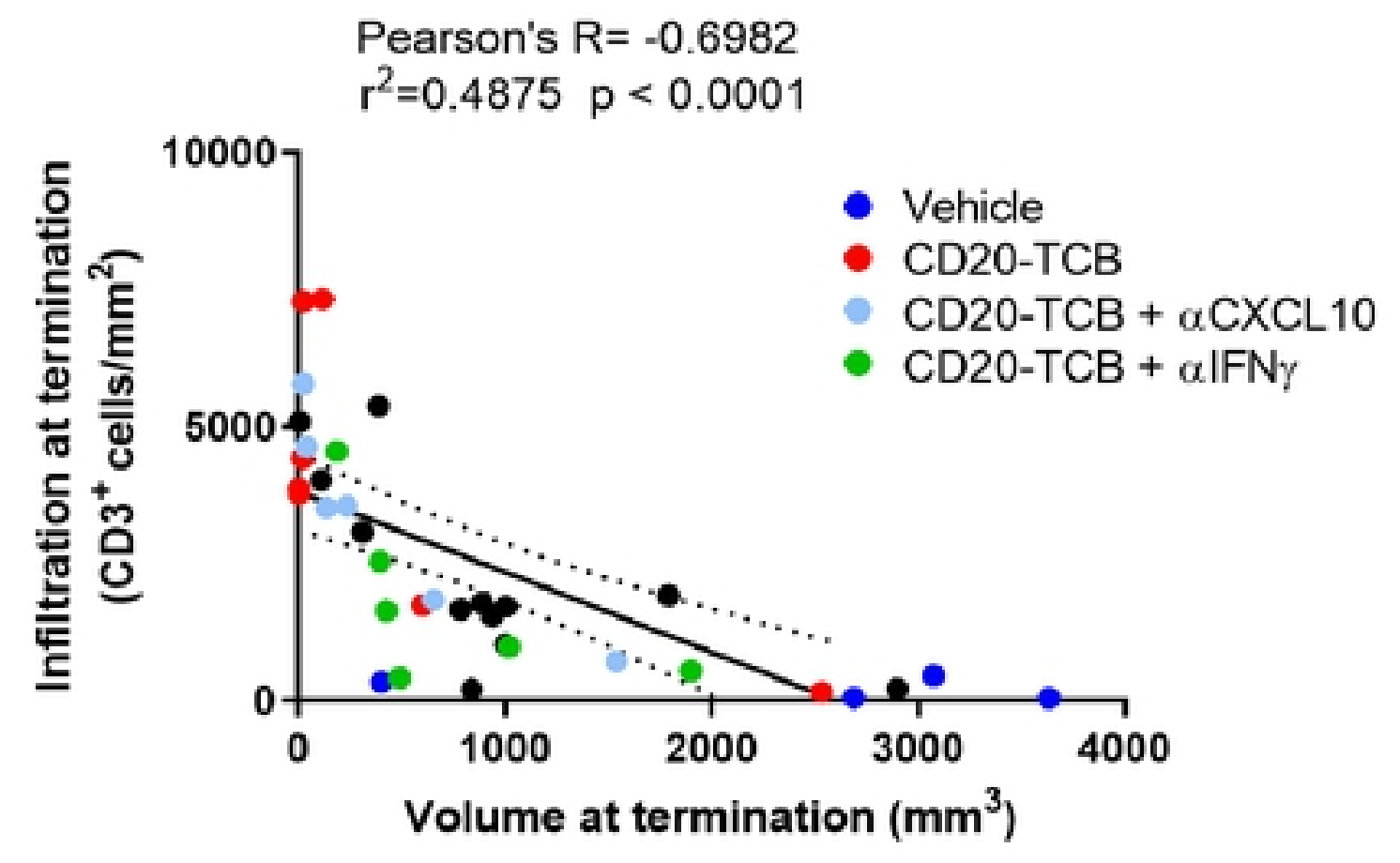

Fig. 6: Inhibition of CXCL10 or IFN $\gamma$ impairs CD20-TCB-dependent T cell infiltration

a) Subcutaneous WSU DLCL2-derived tumors between 200 and $800 \mathrm{~mm}^{3}$ were intravenously treated with $0.5 \mathrm{mg} / \mathrm{kg} \mathrm{CD20-TCB}$ in the presence of $\alpha$ CXCL10 or $\alpha$ IFN $\gamma$ antibodies (10 mg/kg), or with suitable vehicle, once per week. $n=9$. Shown are mean values +/- s.d. for tumor volume over time. Unpaired t-test, ${ }^{*} p<0.05$. b) Representative histology of tumors at termination. Blue: nuclear counterstain, brown: CD3. c) Quantification of infiltration at termination $\left(\mathrm{CD}^{+} \mathrm{T}\right.$ cells per tumor area). Statistics: One-way Anova, ${ }^{* *} \mathrm{p}<$ $0.01, * * * p<0.005$. d) Correlation between infiltration and tumor growth. 